\title{
Chemical quality of bottled mineral waters from markets of Curitiba-PR-Brazil
}

\author{
Éder José dos Santos ${ }^{*}$, Dasio Roberto de Oliveira Junior ${ }^{1}$, Amanda Beatriz Hermann1, \\ Ralph Edward Sturgeon². \\ 1 Instituto de Tecnologia do Paraná - TECPAR - Centro de Tecnologia em Saúde e Meio Ambiente, Curitiba, \\ Paraná, Brasil; ${ }^{2}$ Measurement Science and Standards, National Research Council Canada, Ottawa, Canada.
}

\begin{abstract}
Twenty-seven bottled mineral waters from local markets in Curitiba, State of Paraná, Brazil were analyzed for a number of constituents, including: $\mathrm{pH}$, conductivity, total dissolved solids, hardness, $\mathrm{HCO}_{3}^{-}$and $\mathrm{CO}_{3}{ }^{2-}$, as well as $\mathrm{Ca}^{2+}, \mathrm{Mg}^{2+}, \mathrm{Na}^{+}, \mathrm{K}^{+}, \mathrm{NH}_{4}^{+}, \mathrm{F}^{-}, \mathrm{Cl}^{-}, \mathrm{NO}_{3}^{-}, \mathrm{NO}_{2}^{-}$and $\mathrm{SO}_{4}{ }^{2-}$ by ion chromatography (IC); $\mathrm{Al}, \mathrm{Ba}, \mathrm{Cd}, \mathrm{Cr}, \mathrm{Cu}, \mathrm{Fe}, \mathrm{Li}$, $\mathrm{Mn}, \mathrm{Ni}, \mathrm{Sr}, \mathrm{V}$ and $\mathrm{Zn}$ by inductively coupled plasma optical emission spectrometry (ICP OES); Hg by cold vapor generation-ICP OES and $\mathrm{As}, \mathrm{Pb}, \mathrm{Sb}$ and $\mathrm{Se}$ by ICP-mass spectrometry (ICP-MS). The obtained limits of quantitation (LOQ) were adequate for the determination of all analytes using the various analytical techniques. Results for the analysis of AccuStandard certified reference materials QCS-01-5, QCS-02-R1-5 and TCLP-02-1 as well as spike recoveries to samples show acceptable values, within 90-111\% of expected concentrations with relative standard deviations below $10 \%$, demonstrating the accuracy of the determinations. Both $\mathrm{NO}_{2}^{-}$and $\mathrm{NO}_{3}^{-}$ were above the maximum limits set by Brazilian legislation in two samples, indicating a microbiological contamination. One imported sample presented As $\left(6.1 \pm 0.2 \mu \mathrm{g} \mathrm{L}^{-1}\right)$ near the maximum limit $\left(10 \mu \mathrm{g} L^{-1}\right)$ while all other elements of interest were below the values specified by Brazilian legislation. Principal component analysis revealed that four imported samples and one from the Minas Gerais State have the highest mineral concentrations.
\end{abstract}

Key words: bottled mineral waters, elemental composition, chemical quality, principal component analysis.

\footnotetext{
*Authors for correspondence: eder@tecpar.br
} 


\section{INTRODUCTION}

Increased consumption of bottled mineral waters in recent decades implies a greater need for quality monitoring. Knowledge of the chemical composition is necessary to assure the quality of such products (Ikem et al., 2002). Their consumption is increasing in large cities, in part because of doubts over the quality of water supplies. Water provides essential elements such as calcium, magnesium, iron, and others which have proven therapeutic properties. However, mineral water may also naturally contain contaminants such as metals or non-metals toxic to human health. The origin of bottled waters can be quite diverse and includes aquifers, springs, reservoirs or even tap water. In many cases, the source of the water is not clearly specified on the label and so investigation of the quality is necessary (Astel et al., 2014). In Brazil, in accordance with RDC Resolution No. 274/2005 of the Ministry of Health, mineral water is "water obtaineddirectly fromnaturalorgroundwater extractionsources". Concern overthe qualityof mineral wateron the marketis highlightedin several articles devoted to this subject.Ikem et al. investigated the chemical quality of twenty-five bottled waters from cities in the state of Alabama, USA, through a one-wayparametricanalysisof variance(ANOVA) and showed thatseveralsamplesavailable on the markethadphysical-chemical parameters $(\mathrm{pH}$ and conductivity) as well as essential and non-essential elements exceeding the EU and US EPA drinking water standards (Ikem et al., 2002). Saleh et al. evaluated five major brands of commercial bottled water from Egypt. Inorganic constituents and trihalomethanes in all samples were within the acceptable levels of the World Health Organization (WHO) guidelines (Saleh et al., 2001). Dinelli et al. investigated a large number of chemical parameters when comparing the quality of 178 mineral and 158 tap waters bottled in Italy (Dinelli et al., 2012). Recently, Astel et al. presented a study of forty-seven different brands of bottled sparkling and mineral waters from Poland using hierarchical cluster analysis (Astel et al., 2014) and Felipe-Sotelo et al. published a comparison of thirty seven different bottled waters from British and continental Europe using multivariate analysis (Felipe-Sotelo et al., 2015). In these studies, the concentrations ofinorganicions as well as parameterssuch aspH, electrolyticconductivity and inorganicand total organiccarbon were determined. For thispurpose, the main analytical techniques employed were ion chromatography (IC), inductively coupled plasma optical emission spectrometry (ICP OES) and inductively coupled plasma mass spectrometry (ICP-MS). In Brazil, studies have also highlightedconcern over thequality and compositionof bottled mineral waters available on the market. Godoy et al. investigated the natural radionuclides ${ }^{228} \mathrm{Ra},{ }^{226} \mathrm{Ra}$ and ${ }^{210} \mathrm{~Pb}$ in Brazilian bottled mineral waters (Godoy et al., 2001). A physical-chemical evaluation of bottled mineral waters marketed in Campinas, SP, Brazil was made by Morgano et al. (Morgano et al., 2002), Dias et al. evaluated the quality of thirty-two samples of commercially available bottled mineral waters from South and Southeast Brazil (Dias et al., 2012) and Zan et al. investigated the quality of bottled mineral waters available in cities from the Jamari valley, western Amazon, Brazil-Rondônia (Zan et. al., 2013). The objective of this complimentary study was to evaluate the quality of twenty-seven samples of bottled mineral waters from markets in Curitiba - PR - Brazil, taking into account acceptable levels of components stipulated in Brazilian legislation ( $\left.\mathrm{RDC} \mathrm{N}^{\circ} 274,2005\right)$, mineral classification according to Portaria DNPM 540 and Decreto-Lei 7841, as well as information declared on the sample labels. A multivariate statistical analysis of the data was conducted to assess the variability of the composition (Portaria DNPM 540, 2014 and Decreto-Lei 7841, 1945). To the best of our knowledge, such a complete study as this, involving characterization of a variety of sources of bottled waters available for consumption in Brazil for their chemical and physical parameters, mineral constituents and toxic elements, has not been earlier conducted.

\section{MATERIALS AND METHODS}

Instrumentation: Aluminum, $\mathrm{Ba}, \mathrm{Cd}, \mathrm{Cr}, \mathrm{Cu}, \mathrm{Fe}$, $\mathrm{Li}, \mathrm{Mn}, \mathrm{Ni}, \mathrm{Sr}, \mathrm{V}$ and $\mathrm{Zn}$ were determined using a VISTA PRO simultaneous axial view ICP OES spectrometer (Varian, Mulgrave, Australia). Mercury was determined by cold vapor generation (CVG) coupled to ICP OES. Arsenic, Sb, $\mathrm{Pb}$ and Se were determined using a Varian model 820-MS (ICP-MS). Argon and $\mathrm{H}_{2}$ of $99.99995 \%$ purity were supplied by White Martins (São Paulo, Brazil) for plasma operation. Optimized 
experimental conditions are summarized in Table 1 .

Table 1. ICP OES, CVG-ICP OES and ICP-MS instrumental parameters.

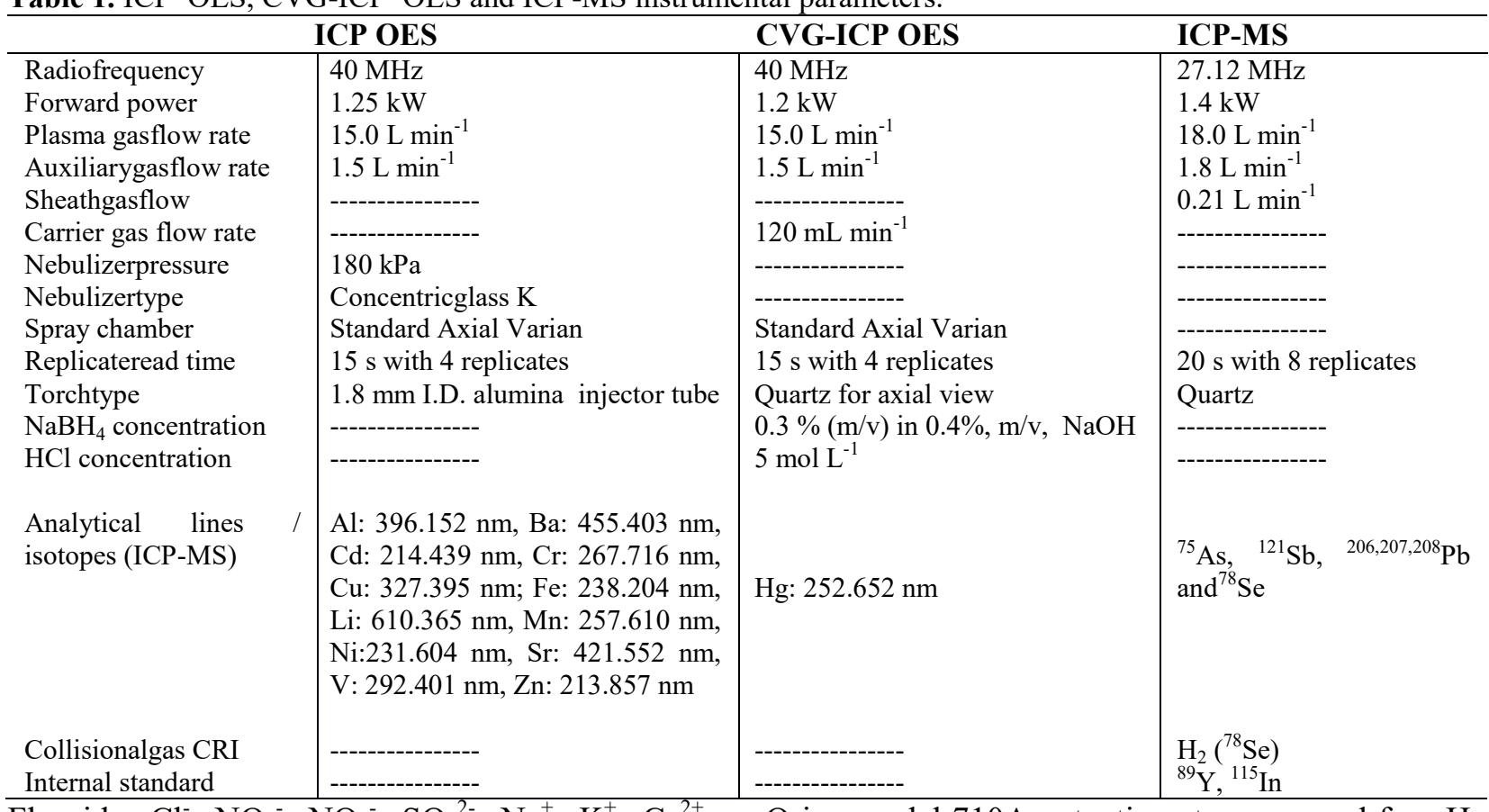

Fluoride, $\mathrm{Cl}^{-}, \mathrm{NO}_{3}^{-}, \mathrm{NO}_{2}^{-}, \mathrm{SO}_{4}{ }^{2-}, \mathrm{Na}^{+}, \mathrm{K}^{+}, \mathrm{Ca}^{2+}$, $\mathrm{Mg}^{2+}$ and $\mathrm{NH}_{4}^{+}$were determined using a model Dionex ICS-5000+ IC from Thermo Fischer Scientific (Sunnyvale, CA, USA). Experimental conditions are summarized in Table 2. A Thermo

Orion model 710A potentiometer was used for $\mathrm{pH}$ measurements. Conductivity and Total Dissolved Solids (TDS) were acquired with a Mettler Toledo (Schwerzenbach, Switzerland) model SevenCompact $\mathrm{pH}$ meter.

Table 2. IC operating parameters.

\begin{tabular}{|c|c|}
\hline & Anions \\
\hline Column & IonPac $\AA$ AS19 2x250mm \\
\hline GuardColumn & IonPac $\AA$ AG19 2x50mm \\
\hline Eluent & $20 \mathrm{mmol} \mathrm{L}^{-1} \mathrm{KOH}$ \\
\hline Flow & $0.25 \mathrm{~mL} \mathrm{~min}^{-1}$ \\
\hline Temperature & $30^{\circ} \mathrm{C}$ \\
\hline Suppressor & $13 \mathrm{~mA}$ \\
\hline Detector & Conductivity \\
\hline Injection loop & $10 \mu \mathrm{L}$ \\
\hline Run time & $20 \mathrm{~min}$ \\
\hline
\end{tabular}

Cations
IonPac $\AA$ AS12A $2 \times 250 \mathrm{~mm}$
IonPac $\AA$ AG12A $2 \times 50 \mathrm{~mm}$
$10 \mathrm{mmol} \mathrm{L}^{-1} \mathrm{H}_{2} \mathrm{SO}_{4}$
$0.25 \mathrm{~mL} \mathrm{~min}^{-1}$
$30^{\circ} \mathrm{C}$
$15 \mathrm{~mA}$
Conductivity
$10 \mu \mathrm{L}$
$20 \mathrm{~min}$

Reagents and samples: All chemicals were of analytical grade, unless otherwise specified. Highpurity water (18.2 $\mathrm{M} \square \mathrm{cm}$ resistivity) was deionized in a Milli-Q system (Bedford, MA, USA). The following Merck reagents (Darmstadt, Germany) were used: $\mathrm{NaBH}_{4}$ to prepare a $0.3 \%$ $\mathrm{m} / \mathrm{v}$ solution in $\mathrm{NaOH} ; 65 \% \mathrm{v} / \mathrm{v} \mathrm{HNO}_{3}$ suprapur ${ }^{\circledR}$; $37 \% \mathrm{v} / \mathrm{v} \mathrm{HCl}$ from which a $5 \mathrm{~mol} \mathrm{~L}^{-1}$ solution was prepared. Buffer solutions for $\mathrm{pH} 4.00$ and $\mathrm{pH}$ 7.00 were supplied by Êxodo (Hortolândia, Brasil). Monoelemental standard solutions containing $1000 \square \mathrm{g} \mathrm{mL}^{-1}$ of $\mathrm{Al}, \mathrm{As}, \mathrm{Hg}, \mathrm{In}, \mathrm{K}^{+}$, $\mathrm{Mn}, \mathrm{Na}^{+}, \mathrm{Pb}, \mathrm{Se}, \mathrm{Sb}, \mathrm{Sr}, \mathrm{V}, \mathrm{Y}, \mathrm{Zn}, \mathrm{Cl}^{-}, \mathrm{NO}_{2}{ }^{-}$and $\mathrm{NH}_{4}^{+}$were obtained from AccuStandard (New Haven, USA); those for $\mathrm{Ba}, \mathrm{Cd}, \mathrm{Cr}, \mathrm{Ca}^{2+}, \mathrm{Cu}, \mathrm{Fe}$,

$\mathrm{Li}, \mathrm{Mg}^{2+}$ and $\mathrm{Ni}$ from UltraScientific (North Kingstown, USA), while solutions of $\mathrm{F}^{-}, \mathrm{NO}_{3}{ }^{-}$and $\mathrm{SO}_{4}{ }^{2-}$ were supplied by FlukaAnalitical (St. Louis, USA). A conductivity standard of $84 \mu \mathrm{S} \mathrm{cm}^{-1}$ was obtained from Mettler Toledo. Quality control Certified Reference Materials comprising acidified aqueous solutions containing $100 \mu \mathrm{g} \mathrm{mL}^{-1} \mathrm{As}, \mathrm{Sb}$, $\mathrm{Ca}, \mathrm{Cd}, \mathrm{Cr}, \mathrm{Cu}, \mathrm{Fe}, \mathrm{Li}, \mathrm{Mg}, \mathrm{Mn}, \mathrm{Ni}, \mathrm{Pb}, \mathrm{Se}, \mathrm{Sr}, \mathrm{V}$ and $\mathrm{Zn}$ (QCS-01-5), $100 \mu \mathrm{g} \mathrm{mL}^{-1}$ of Al, Ba, K and $\mathrm{Na}$ (QCS-02-R1-5) and $20 \mu \mathrm{g} \mathrm{mL}^{-1}$ of Hg (TCLP02-1) were obtained from AccuStandard. These served asquality control standards. Twenty-seven samples of bottled mineral waters were purchased from local markets in Curitiba city, State of Paraná (PR)-Brazil and included twenty samples from 
Paraná State, one from São Paulo State, one from Minas Gerais State, one imported from Portugal, two imported from France and two imported from Italy. Information regarding the mineral composition available on the labels of these samples is presented in Table 3.

Analytical procedures and standard
calibration: All samples were simply acidified to
$1 \%$ v/v $\mathrm{HNO}_{3}$ for determination of elements by
$\mathrm{ICP} \mathrm{OES}, \mathrm{ICP}_{\mathrm{MS}}$ and $\mathrm{Hg}$ by $\mathrm{CVG}-\mathrm{ICP} \mathrm{OES}$.For
the determination of analytes by IC, aliquots of the
samples were injected directly, or diluted
appropriately when the analyte concentration
present in the samples presented a concentration
greater than the working range, without any
preliminary treatment.
Hydrogen carbonate $\left(\mathrm{HCO}_{3}{ }^{-}\right)$, carbonate $\left(\mathrm{CO}_{3}{ }^{2-}\right)$
and Hardness were determined by titrimetry. All
determinations were made following the
recommendations in Standard Methods for the
Examination of Water and Wastewater, 2012.

Multielement standard calibration solutions spanning the concentration range $100-2000 \mu \mathrm{g} \mathrm{L}$ ${ }^{-1}$ for $\mathrm{Al}, \mathrm{Ba}, \mathrm{Cd}, \mathrm{Cr}, \mathrm{Cu}, \mathrm{Fe}, \mathrm{Li}, \mathrm{Mn}, \mathrm{Ni}, \mathrm{Sr}, \mathrm{V}$ and $\mathrm{Zn}$ were prepared in $1 \% \mathrm{v} / \mathrm{v} \mathrm{HNO}_{3}$ for their determination by ICP OES; for $\mathrm{Hg}$ the calibration standards were prepared in $1 \% \mathrm{v} / \mathrm{v} \mathrm{HNO}_{3}$ spanning the range $0.2-1.0 \mu \mathrm{g} \mathrm{L}^{-1}$, and for determination of $\mathrm{As}, \mathrm{Pb}, \mathrm{Sb}$ and $\mathrm{Se}$ by ICP-MS, multielement calibration curves were prepared in $1 \% \mathrm{v} / \mathrm{v} \mathrm{HNO}_{3}$ spanning the range $1.0-20 \mu \mathrm{g} \mathrm{L}^{-1}$.Operating conditions summarized in Table 1 were used. For determination of analytes by IC, multielement standard solutions containing $\mathrm{Ca}^{2+}, \mathrm{Mg}^{2+}, \mathrm{K}^{+}, \mathrm{Na}^{+}$ in the range $0.1-2.0 \mathrm{mg} \mathrm{L}^{-1}$ and $\mathrm{NH}_{4}{ }^{+}$in the range $0.03-0.5 \mathrm{mg} \mathrm{L}^{-1}$ were prepared in de-ionized water and a multielement calibration standard solution for $\mathrm{F}^{-}, \mathrm{Cl}^{-}, \mathrm{NO}_{3}^{-}, \mathrm{SO}_{4}{ }^{2-}$ and $\mathrm{NO}_{2}^{-}$was prepared in de-ionized water spanning the ranges $0.01-10 \mathrm{mg}$ $\mathrm{L}^{-1}$. Analytical conditions summarized in Table 2 were used.

Statistical evaluation: The statistical program Statgraphics Plus 5.0 (Statgraphics Graphics Corp., ST. SC., USA) was used for principal component analysis (PCA). 
Table 3. Mineral composition presented on sample labels of tested bottled mineral waters.

\begin{tabular}{|c|c|c|c|c|c|c|c|c|c|c|c|c|c|c|}
\hline sample & pH & $\begin{array}{c}\text { Cond. } \\
\left(\mu \mathrm{S} \mathrm{cm}^{-1}\right)\end{array}$ & $\begin{array}{c}\mathrm{HCO}_{3}^{-} \\
\left(\mathrm{mg} \mathrm{L}^{-1}\right)\end{array}$ & $\underset{\left(m g ~^{-1}\right)}{F^{-}}$ & $\underset{\left(\mathrm{mg} \mathrm{L}^{-1}\right)}{\mathrm{Cl}^{-}}$ & $\begin{array}{c}\mathrm{NO}_{3}^{-} \\
\left(\mathrm{mg} \mathrm{L}^{-1}\right)\end{array}$ & $\begin{array}{c}\mathrm{SO}_{4}{ }^{2-} \\
\left(\mathrm{mg} \mathrm{L}^{-1}\right)\end{array}$ & $\begin{array}{c}\mathrm{Na}^{+} \\
\left(\mathrm{mg} \mathrm{L}^{-1}\right)\end{array}$ & $\begin{array}{c}\mathbf{K}^{+} \\
\left(\mathbf{m g ~ L}^{-1}\right)\end{array}$ & $\begin{array}{c}\mathbf{M g}^{2+} \\
\left(\mathrm{mg} \mathrm{L}^{-1}\right)\end{array}$ & $\underset{\left(\mathrm{mg} \mathrm{L}^{-1}\right)}{\mathrm{Ca}^{2+}}$ & $\underset{\left(\mathrm{mg} \mathrm{L}^{-1}\right)}{\mathbf{B a}}$ & $\begin{array}{c}\mathrm{Sr} \\
\left(\mathrm{mg} \mathrm{L}^{-1}\right)\end{array}$ & $\begin{array}{c}\mathbf{L i} \\
\left(\mathrm{mg} \mathrm{L}^{-1}\right)\end{array}$ \\
\hline 01 & 5.22 & 153 & 2.09 & 0.01 & ---- & ---- & ---- & 0.2 & 0.1 & 0.12 & 0.27 & 0.007 & 0.003 & --- \\
\hline 02 & 5.10 & 10 & 3.2 & 0.02 & 0.15 & ---- & 0.3 & 0.38 & 1.47 & 0.07 & 0.12 & ---- & ---- & ---- \\
\hline 03 & 6.88 & 111.5 & 75.35 & 0.07 & 0.6 & 2.8 & 0.2 & 6.2 & 0.2 & 1.82 & 17.65 & ---- & 0.015 & ---- \\
\hline 04 & 6.88 & 111.5 & 75.35 & 0.07 & 0.6 & 2.8 & 0.2 & 6.2 & 0.2 & 1.82 & 17.65 & ---- & 0.015 & ---- \\
\hline 05 & 5.98 & 83 & 37.2 & 0.09 & 1.94 & 7.27 & 0.36 & 6.592 & 3.595 & 1.832 & 5.346 & 0.09 & 0.151 & ---- \\
\hline 06 & 8.66 & 108.4 & 62.49 & 0.05 & $<0.09$ & ---- & 0.18 & 16.09 & 1.485 & 0.34 & 7.792 & ---- & 0.343 & ---- \\
\hline 07 & 7.60 & 254 & 146.62 & 0.02 & 0.64 & ---- & ---- & 1.079 & 0.542 & 14.29 & 24.88 & ---- & 0.019 & ---- \\
\hline 08 & 5.45 & 48 & 16.8 & 0.03 & 0.85 & 7 & 0.7 & 0.98 & 1.89 & 1.82 & 3.73 & 0.064 & 0.042 & --- \\
\hline 09 & 5.68 & 31.2 & 15.59 & --- & 0.34 & 2 & 1.4 & 1.17 & 1.63 & 1.54 & 2.15 & 0.057 & 0.022 & 0.022 \\
\hline 10 & 5.48 & 130.7 & 26.28 & 0.02 & 6.72 & 3.47 & ---- & 4.01 & 0.3 & 6.46 & 13.05 & 0.087 & 0.073 & --- \\
\hline 11 & 6.96 & 157.5 & 92.7 & 0.05 & 2.47 & 6.4 & 0.4 & 8 & 2.03 & 5.62 & 16.94 & 0.006 & 0.107 & --- \\
\hline 12 & 6.79 & 211 & 118.79 & 0.3 & 3.38 & ---- & 2.34 & 10.8 & 2.103 & 6.359 & 21.39 & 0.01 & 0.154 & 0.005 \\
\hline 13 & 7.92 & 233 & 131.19 & 0.82 & 2.54 & ---- & 3.45 & 6.844 & 2.086 & 11.16 & 23.22 & ---- & ---- & ---- \\
\hline 14 & 7.36 & 303 & 187.38 & 0.03 & --- & ---- & 0.65 & 1.52 & 0.87 & 22.08 & 36.76 & 0.024 & ---- & --- \\
\hline 15 & 7.09 & 264 & 144.54 & 0.36 & 3.82 & 0.07 & 12.17 & 33.68 & 1.237 & 0.741 & 23.82 & 0.007 & 0.348 & 0.013 \\
\hline 16 & 6.83 & 215 & 116.21 & 0.06 & 3.04 & 20.14 & 0.84 & 7.009 & 0.958 & 8.753 & 25.8 & 0.005 & 0.127 & ---- \\
\hline 17 & 9.17 & 195.8 & 92.09 & 0.19 & 0.83 & 10 & 0.68 & 33.67 & 0.598 & 3.141 & 9.507 & ---- & 0.054 & ---- \\
\hline 18 & 6.73 & 267 & 128.91 & 0.07 & 3.31 & 12.56 & 2.15 & 8.042 & 0.572 & 10.39 & 30.83 & ---- & 0.075 & ---- \\
\hline 19 & 7.13 & 317 & 205.57 & 0.02 & 1.43 & 2.93 & 0.2 & 2.429 & 0.874 & 17.72 & 37.6 & 0.028 & 0.019 & ---- \\
\hline 20 & 7.13 & 421 & 296.27 & ---- & 1.39 & 1.82 & 1.14 & 1.466 & 1.156 & 28.94 & 49.53 & 0.044 & 0.052 & ---- \\
\hline 21 & 7.47 & 335 & 199.63 & 0.02 & --- & 5.08 & 0.23 & 0.919 & 0.368 & 21.07 & 32.5 & 0.007 & ---- & --- \\
\hline 22 & 5.37 & 464 & 282.8 & 0.12 & 1.53 & 1.83 & 1.79 & 33.49 & 32.93 & 12.38 & 28.41 & 0.464 & 0.049 & 0.028 \\
\hline 23 & 5.5 & 780 & 430 & ---- & 22 & 7.8 & 33 & 9.5 & $<1$ & 4.2 & 160 & ---- & ---- & ---- \\
\hline 24 & 6 & ---- & 1300 & 1.2 & 44 & ---- & 38 & 165 & 10 & 85 & 190 & ---- & ---- & ---- \\
\hline 25 & 6.10 & 2670 & 2044 & 1.3 & 29.4 & 0.19 & ---- & 599 & 30.6 & 24.6 & 101 & ---- & ---- & ---- \\
\hline 26 & 7.6 & 1125 & 245 & ---- & 52 & 2.6 & 430 & 33.3 & 2.2 & 51.4 & 174 & ---- & 2.8 & ---- \\
\hline 27 & 8 & 216 & 103 & ---- & 8.5 & 2.9 & 22 & 6.4 & 0.8 & 6.2 & 32 & ---- & ---- & ---- \\
\hline
\end{tabular}




\section{RESULTS AND DISCUSSION}

\section{Figures of merit and precision}

Analytical figures of merit derived from the results of replicate analysis of seven solutions prepared from acidified standards for determination by ICP OES, CVG-ICP OES and ICP-MS, as well as that for analysis of seven solutions prepared in unacidified de-ionized water for determination by IC are summarized inTable 4. The linear correlation coefficients range from 0.9980 to 0.9999 , demonstrating adequate linearity. Limits of detection (LOD) were calculated from 3 times the standard deviation of 7 measurements of the blank divided by the slope of the calibration curve. The practical quantification limits (LOQ) provided estimates of the lowest values of concentration could be determined with acceptable precision and accuracy. The LOQ are fit-for-purpose for determination of all analytes of interest. Analyses of the prepared solutions are in agreement (values within $90-111 \%$ ) with expected concentrations with relative standard deviations (RSD) below 10 $\%$, indicating that fit-for-purpose recovery and precision can be achieved following prescribed sample preparation procedures and instrumental calibration (Miller, J.N. and Miller, J.C., 2000)

Table 4. Figures of merit and results for analysis of quality control materials and standards $(n=7)$.

\begin{tabular}{|c|c|c|c|c|c|c|}
\hline Analyte & $\begin{array}{c}\text { Linear } \\
\text { correlationcoefficients }\end{array}$ & $\begin{array}{l}\text { Limit of } \\
\text { detection } \\
\left(\mu \mathrm{g} \mathrm{L}^{-1}\right)\end{array}$ & $\begin{array}{c}\text { Limit of } \\
\text { quantification } \\
\left(\mu \mathrm{g} \mathrm{L}^{-1}\right)\end{array}$ & $\begin{array}{c}\text { expected } \\
\text { concentration } \\
\left(\mu \mathrm{g} \mathrm{L}^{-1}\right)\end{array}$ & recovery & $\begin{array}{c}\mathrm{RSD}, \\
\%\end{array}$ \\
\hline $\mathrm{Al}$ & 0.9998 & 2 & 10 & 10.0 & $\begin{array}{c}10.0 \pm \\
0.2\end{array}$ & 2.0 \\
\hline As & 0.9997 & 0.1 & 1.0 & 10.0 & $\begin{array}{c}10.3 \pm \\
0.2\end{array}$ & 1.9 \\
\hline $\mathrm{Ba}$ & 0.9999 & 1 & 5 & 10.0 & $\begin{array}{c}11.0 \pm \\
0.1\end{array}$ & 0.9 \\
\hline $\mathrm{Ca}^{2+}$ & 0.9999 & 10 & 100 & 100 & $106 \pm 4$ & 4 \\
\hline $\mathrm{Cd}$ & 0.9999 & 0.2 & 1.0 & 10.0 & $9.6 \pm 0.1$ & 1.0 \\
\hline $\mathrm{Cu}$ & 0.9996 & 1 & 10 & 10.0 & $\begin{array}{c}10.1 \pm \\
0.2\end{array}$ & 2.0 \\
\hline $\mathrm{Cr}$ & 0.9999 & 0.2 & 1.0 & 10.0 & $9.8 \pm 0.1$ & 1.0 \\
\hline $\mathrm{Cl}^{-}$ & 0.9999 & 30 & 100 & 100 & $101 \pm 10$ & 10 \\
\hline $\mathrm{F}^{-}$ & 0.9993 & 1 & 20 & 10.0 & $9.1 \pm 0.3$ & 3.3 \\
\hline $\mathrm{Fe}$ & 0.9999 & 2 & 10 & 10.0 & $\begin{array}{c}10.5 \pm \\
0.1\end{array}$ & 1.0 \\
\hline $\mathrm{Hg}$ & 0.9980 & 0.04 & 0.2 & 1.0 & $\begin{array}{l}0.9 \pm \\
0.03\end{array}$ & 3.3 \\
\hline $\mathrm{K}^{+}$ & 0.9999 & 10 & 100 & 100 & $102 \pm 3$ & 3 \\
\hline $\mathrm{Li}$ & 0.9996 & 2 & 10 & 10.0 & $\begin{array}{c}11.2 \pm \\
0.2\end{array}$ & 1.8 \\
\hline $\mathrm{Mn}$ & 0.9999 & 0.2 & 1.0 & 10.0 & $\begin{array}{c}10.2 \pm \\
0.2\end{array}$ & 1.8 \\
\hline $\mathrm{Mg}^{2+}$ & 0.9999 & 5 & 100 & 100 & $98 \pm 2$ & 2 \\
\hline $\mathrm{NO}_{3}^{-}$ & 0.9999 & 5 & 100 & 100 & $89 \pm 1$ & 1 \\
\hline $\mathrm{NO}_{2}^{-}$ & 0.9999 & 1 & 10 & 10.0 & $\begin{array}{c}10.2 \pm \\
0.3\end{array}$ & 2.9 \\
\hline $\mathrm{NH}_{4}^{+}$ & 0.9999 & 10 & 30 & 30.0 & $\begin{array}{c}33.0 \pm \\
2.1\end{array}$ & 6.4 \\
\hline $\mathrm{Na}^{+}$ & 0.9999 & 10 & 100 & 100 & $100 \pm 4$ & 4 \\
\hline $\mathrm{Ni}$ & 0.9999 & 2 & 10 & 10.0 & $9.5 \pm 0.3$ & 3.2 \\
\hline $\mathrm{Pb}$ & 0.9995 & 0.1 & 1.0 & 10.0 & $\begin{array}{c}10.2 \pm \\
0.2\end{array}$ & 2.0 \\
\hline $\mathrm{Sb}$ & 0.9996 & 0.2 & 1.0 & 10.0 & $\begin{array}{c}11.1 \pm \\
0.3\end{array}$ & 2.7 \\
\hline $\mathrm{Sr}$ & 0.9997 & 1 & 5 & 10.0 & $10.0 \pm$ & 1.0 \\
\hline
\end{tabular}




\begin{tabular}{ccccccc} 
& & & & 0.1 & \\
$\mathrm{Se}$ & 0.9987 & 0.1 & 1.0 & 10.0 & $10.1 \pm$ & 1.0 \\
$\mathrm{SO}_{4}{ }^{2-}$ & & & & & 0.1 & \\
$\mathrm{~V}$ & 0.9999 & 10 & 100 & 100 & $98 \pm 2$ & 2.0 \\
$\mathrm{Zn}$ & 0.9999 & 2 & 10 & 10.0 & $9.0 \pm 0.1$ & 1.1 \\
\hline
\end{tabular}

\section{Trace elements and contaminants}

Tables 5 and 6 summarize results obtained characterizing the twenty-seven commercial samples purchased for this study. The presence of $\mathrm{NH}_{4}^{+}$and $\mathrm{NO}_{2}^{-}$are indicative of microbiological contamination. The concentration of $\mathrm{NH}_{4}^{+}$was below the limit of quantification but for $\mathrm{NO}_{2}^{-}$ samples 14, 19 and $21 \quad\left(0.01 \quad \mathrm{mg} \mathrm{L}^{-1}\right)$ concentrations nearthemaximum limit setby Brazilian legislation were evident whereas that for sample $16\left(0.04 \mathrm{mg} \mathrm{L}^{-1}\right)$ exceeded the maximum limit set by $\mathrm{RDC} \mathrm{N}^{\circ} 274$, 2005, i.e., $0.02 \mathrm{mg} / \mathrm{L}$. In such cases, microbiological testing is required. Toxic elements such as $\mathrm{Cd}, \mathrm{Hg}, \mathrm{Ni}, \mathrm{Pb}$ and $\mathrm{Cu}$ were all present below their LOQ and hence below the maximum values specified by Brazilian legislation (RDC $\mathrm{N}^{\circ}$ 274, 2005). Arsenic, Cr, Mn, $\mathrm{Sb}$ and $\mathrm{Zn}$ were detected in some samples: As in five samples was present from 1.1 to $6.1 \mu \mathrm{g} \mathrm{L}^{-1} ; \mathrm{Cr}$ in six samples occurred in the range $1.3-4.9 \mu \mathrm{g} \mathrm{L}$ ${ }^{1}$; $\mathrm{Mn}$ in eight samples was in the range 1.1 - 155.6 $\mu \mathrm{g} \mathrm{L}^{-1} ; \mathrm{Sb}$ was present in two samples at $1.0 \mu \mathrm{g} \mathrm{L}^{-1}$ and $2.3 \mu \mathrm{g} \mathrm{L}^{-1}$, and $\mathrm{Zn}$ in three samples was quantified at $14 \mu \mathrm{g} \mathrm{L}^{-1}, 22 \mu \mathrm{g} \mathrm{L}^{-1}$ and $37 \mu \mathrm{g} \mathrm{L}^{-1}$. All were below the maximum specified by Brazilian legislation, i.e., As $10 \mu \mathrm{g} \mathrm{L}^{-1}$, Cr $50 \mu \mathrm{g}$ $\mathrm{L}^{-1}$, Mn $500 \mu \mathrm{g} \mathrm{L}^{-1}, \mathrm{Sb} 5 \mu \mathrm{g} \mathrm{L}^{-1}$ (RDC N $\mathrm{N}^{\circ} 274$, 2005) and $\mathrm{Zn} 500 \mu \mathrm{g} \mathrm{L}^{-1}$ (Portaria 2914/2011). Further investigation would be required to determine the origin of these elements, whether natural or anthropogenic. Detectable aluminium is detected in only one sample from Brazil (sample 22 from Minas Gerais State) whereas all imported samples lie in the range $10-30 \mu \mathrm{g} \mathrm{L}^{-1}$. As $\mathrm{Al}$ has no known biochemical function (Silva Pereira and Dos Reis, 2012), Brazilian legislation specifies a tolerable limit of $200 \mu \mathrm{g} \mathrm{L}^{-1}$ in drinking water (Portaria 2914/2011). Iron is only detected in two imported samples from Italy: $10 \mu \mathrm{g} \mathrm{L}^{-1}$ (sample 26) and $21 \mu \mathrm{g} \mathrm{L} \mathrm{L}^{-1}$ (sample 27), but its concentration is notdeclared on the sample labels.Selenium is present in the range $1.2-6.4 \mu \mathrm{g}$ $\mathrm{L}^{-1}$ (four samples) and $\mathrm{V}$ in the range $10-150 \mu \mathrm{g}$ $\mathrm{L}^{-1}$ (ten samples). Sample 24, imported from France, and sample 17, from Paraná State, are identified as containing the highest concentrations of Se: $6.4 \pm 0.3 \mu \mathrm{g} \mathrm{L}^{-1}$ and V: $150 \pm 5 \mu \mathrm{g} \mathrm{L}^{-1}$, respectively. According to Brazilian legislation, these samples should also beclassified as mineral waters "seleniada", i.e., that containselenium at minimum $6 \mu \mathrm{g} \mathrm{L}^{-1}$ and maximum of $10 \mu \mathrm{g} \mathrm{L}^{-1}$, and "vanadica", i.e., that contain vanadium at minimum $30 \mu \mathrm{g} \mathrm{L}^{-1}$ (Portaria DNPM 540, 2014 and RDC N ${ }^{\circ}$ 274, 2005). However, no statementon the label can be found. With respect to trace element content and potential contaminants, all samplesshould have more information concerning their concentrations.

Major and constituent elements 
Although the physico-chemical parameter $\mathrm{pH}$ showed values different from those declared on the labels, as summarized in Table 3, these differences were not significant and in these cases the producers indicate that the values correspond to those characterizing the source of the water. These differences are acceptable since chemical transformations may occur over time that could slightly affect the $\mathrm{pH}$.The $\mathrm{pH}$ range varies from mildly acidic $(5.53 \pm 0.01$, sample 23$)$ toslightlyalkaline (8. $89 \pm 0.10$, sample 24$)$. Alkalinitydueto the presence of $\mathrm{CO}_{3}{ }^{2-}$ was detected in four sampleswherein thereported pHwas $8.49 \pm$ 0.01 (sample 14), $8.79 \pm 0.03$ (sample 17), $8.44 \pm$ 0.05 (sample 19) and $8.89 \pm 0.01$ (sample 24). Figure 1shows thecorrelation betweenconductivity and total dissolved solids (TDS)parameterswhich indicatesthat the higher thesample conductivity, the greater the amount ofTDS present. These two parameters are strongly correlated, especially with imported samples 24 (France), 25 (Portugal) and 26 (Italy). Conductivity is in close agreement with declared values except for sample 01 for which a value of $3.7 \pm 0.1 \mu \mathrm{S} \mathrm{cm}^{-1}$ was determined whereas $153 \mu \mathrm{S} \mathrm{cm}^{-1}$ declared, and the producer will require notification.

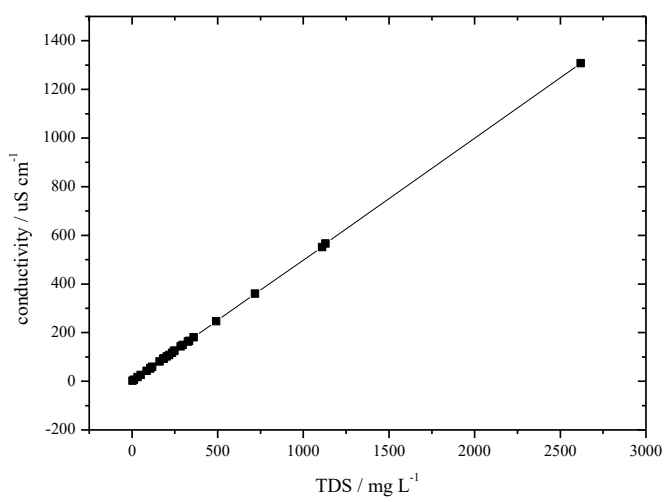

Figure 1. Correlation between conductivity and TDS.

Likewise,thehardnesspresent in the samplecan be correlatedmainlyto the presenceof $\mathrm{Ca}$ and $\mathrm{Mg}$. Samples24-26 are again highlighted for their significant values present. The main constituent elements reportedon the sample labels include: $\mathrm{HCO}_{3}^{-}, \mathrm{F}^{-}, \mathrm{Cl}^{-}, \mathrm{NO}_{3}^{-}, \mathrm{SO}_{4}{ }^{2-}, \mathrm{Na}^{+}, \mathrm{K}^{+}, \mathrm{Mg}^{2+}, \mathrm{Ca}^{2+}$, $\mathrm{Ba}, \mathrm{Li}$ and $\mathrm{Sr}$. Principal component analysis (PCA) for the concentrations of these analytes is presented in Figure 2, where $\mathrm{PC} 1$ is the first principal component, $\mathrm{PC} 2$ is the second and $\mathrm{PC} 3$ is the third (Dos Santos et al., 2008, Dos Santos et. al., 2012 and Miller, J. N. and Miller, J. C, 2000). PC1 accounts for $47 \%$ of the variance of the data and discriminates samples through the influence of parameters related to $\mathrm{HCO}_{3}^{-}, \mathrm{F}^{-}, \mathrm{Cl}^{-}, \mathrm{Ca}^{2+}$, and $\mathrm{Li}$. PC2 accounts for $17 \%$ of the variance of the data and discriminates samples on the basis of $\mathrm{SO}_{4}{ }^{2-}$, while PC 3 accounts for $12 \%$ of the variance of the data and is mainly correlated with the presence of $\mathrm{Ba}$ and Sr. Together, $76 \%$ of the variability of the original data is thus accounted for. As evident from Figure 2, the samples are clustered in a main group but five are located in differentregions of thegraph. Samples 23 to 26 are imported: 23 and 24 from France, 25 from Portugal and 26 from Italy. Only sample 22 is from Minas Gerais State, Brazil. Is evident that these samples havedifferentphysicochemicalcompositions, being characterized by relatively high concentrations of salts, manly $\mathrm{HCO}_{3}^{-}$and Sr. Legislation does not specify a value for $\mathrm{Sr}$, and the $\mathrm{HCO}_{3}{ }^{-}$ion is an essential component of mineral waters (DecretoLei 7841, 1945). These fivesamplesare also rich $\mathrm{inF}^{-}$, providing a classification as "fluoridated mineral water", as defined by Brazilian legislation (Portaria DNPM 540, 2014). The concentration of Li is high in samples 22, 24, 25 and 26, also a characteristic of mineral water in accordance with Brazilian legislation (Portaria DNPM 540, 2014). The concentration of $\mathrm{Ba}$ in sample 22 is the highest: $386 \pm 5 \mu \mathrm{g} \mathrm{L}^{-1}$, but below the maximum specified by Brazilian legislation, i.e., $700 \mu \mathrm{g} \mathrm{L}^{-1}$ $\left(\mathrm{RDC} \mathrm{N}^{\circ} 274,2005\right)$. The main cluster comprises the majority of the samples that are bottled in the State of Paraná, with the exception of sample 11 from São Paulo State and sample 27 from Italy. This cluster is characteristic of the presence of $\mathrm{NO}_{3}{ }^{-}$. Nitrate may have either a mineral or microbiological origin. Its determinable concentration ranges from $0.10 \mathrm{mg} \mathrm{L}^{-1}-63.05 \mathrm{mg}$ $\mathrm{L}^{-1}$ while samples 01,15 and 25 are below the LOQ. Only sample $10\left(63.05 \mathrm{mg} \mathrm{L}^{-1}\right)$ is above the maximum specified by Brazilian legislation, i.e., $50 \mathrm{mg} / \mathrm{L}\left(\mathrm{RDC} \mathrm{N}^{\circ} 274,2005\right)$, but the label states a value of $3.47 \mathrm{mg} \mathrm{L}^{-1}$ (Table 3). The elevated concentration may be indicative of microbiological contamination which may be harmful tohuman health (Astel et al., 2014). Samples 01, 10 and 21 are classified as "fluoridated mineral water", according to their labels; however, in this study, $\mathrm{F}^{-}$ wasnot detectedabove $0.02 \mathrm{mg} \mathrm{L}^{-1}$,theminimum, according to Brazilian legislation (Portaria DNPM $540,2014)$, needed forwaterto beclassified as such. Since the declared valuesare close to the 
minimum, analytesorptionby

the packagingmaterials may have occurred. It is evident that samples 3 and 4 have the same mineral composition. In reality, these samples are from the same region (Apucarana city, State of Paraná), but on the market they have a different identification and no indication that they are from the same producer. In general, it is clear that information declared on the label is different from that arising from analysis of the samples in this work, but it must also be recognized that as the samples are rich in salts, several factors may lead to changes in the composition, however small, including decomposition of $\mathrm{HCO}_{3}{ }^{-}$, sorption of analytes onto the walls of the container material, the time on the market shelf, and proper care during transport and the ambient storage temperature. To make a more qualified analysis of the national samples, a scatter plot based on only national Brazilian samples is presented in Figure 3. Here the PCs account for $73 \%$ of the variability of the original data. As in Figure 2, variability in the compositions of samples are evident wherein the difference of mineral content of sample 22 in relation to others is evident. The sample 10 possibly is contaminated and the samples 15 and 17 show $\mathrm{F}^{-}$content and $\mathrm{Na}^{+}$higher concentrations than others.Clearly, the PCA statistical tool can be very useful for identification

andcomparison ofcompositionsof bottled mineral waters on the market.

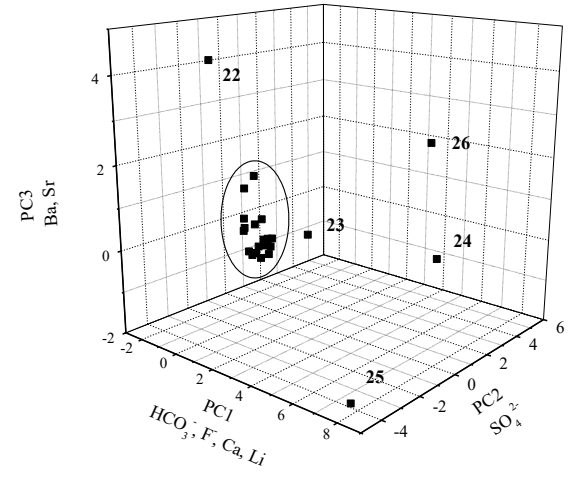

Figure 2. Principal component analysis applied to results obtained for the analysis of twenty-seven samples of bottled mineral water from markets in

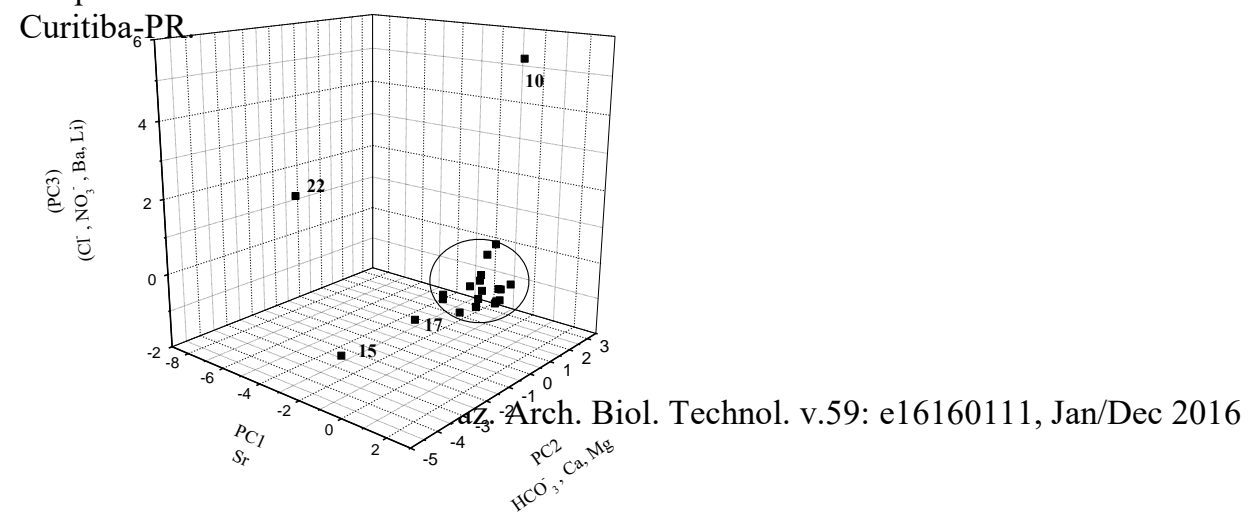

Figure 3. Principal component analysis applied to results obtained for the analysis of only national Brazilian samples of bottled mineral water from markets in Curitiba-PR. 
Table 5. Results for physico-chemical parameters and IC $(n=3)$.

\begin{tabular}{|c|c|c|c|c|c|c|c|c|c|c|c|c|c|c|c|c|}
\hline sample & $\mathrm{pH}$ & $\begin{array}{c}\text { Cond. } \\
\left(\mu \mathrm{S} \mathrm{cm}^{-1}\right)\end{array}$ & $\begin{array}{c}\mathrm{TDS} \\
\left(\mathrm{mg} \mathrm{L}^{-1}\right)\end{array}$ & $\begin{array}{c}\mathrm{HCO}_{3}^{-} \\
\left(\mathrm{mg} \mathrm{L}^{-1}\right)\end{array}$ & $\begin{array}{c}\mathrm{CO}_{3}{ }^{2-} \\
\left(\mathrm{mg} \mathrm{L}^{-1}\right)\end{array}$ & $\begin{array}{c}\mathrm{F}^{-} \\
\left(\mathrm{mg} \mathrm{L}^{-1}\right)\end{array}$ & $\begin{array}{c}\mathrm{Cl}^{-} \\
\left(\mathrm{mg} \mathrm{L}^{-1}\right)\end{array}$ & $\begin{array}{c}\mathrm{NO}_{3}^{-} \\
\left(\mathrm{mg} \mathrm{L}^{-1}\right)\end{array}$ & $\begin{array}{c}\mathrm{NO}_{2}^{-} \\
\left(\mathrm{mg} \mathrm{L}^{-1}\right)\end{array}$ & $\begin{array}{c}\mathrm{SO}_{4}{ }^{2-} \\
\left(\mathrm{mg} \mathrm{L}^{-1}\right)\end{array}$ & $\begin{array}{c}\mathrm{Na}^{+} \\
\left(\mathrm{mg} \mathrm{L}^{-1}\right)\end{array}$ & $\begin{array}{c}\mathrm{K}^{+} \\
\left(\mathrm{mg} \mathrm{L}^{-1}\right)\end{array}$ & $\begin{array}{c}\mathrm{NH}_{4}^{+} \\
\left(\mathrm{mg} \mathrm{L}^{-1}\right)\end{array}$ & $\begin{array}{c}\mathrm{Mg}^{2+} \\
\left(\mathrm{mg} \mathrm{L}^{-1}\right)\end{array}$ & $\begin{array}{c}\mathrm{Ca}^{2+} \\
\left(\mathrm{mg} \mathrm{L}^{-1}\right)\end{array}$ & $\begin{array}{c}\text { Hardness } \\
\left(\mathrm{mg} \mathrm{L}^{-1}\right)\end{array}$ \\
\hline Legislation & ----- & ----- & - & ----- & ---- & $\begin{array}{l}\text { (1) } 0.02 \mathrm{~min} . \\
{ }^{(2)} 2.00 \mathrm{max} .\end{array}$ & ----- & (2) 50 max. & (2) 0.02 max. & - & 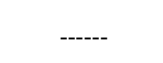 & ----- & & ---- & ----- & ---- \\
\hline 01 & $6.44 \pm 0.17$ & $3.7 \pm 0.1$ & $1.8 \pm 0.1$ & $6.1 \pm 0.1$ & nd & $<0.02$ & 0.20 & $<0,10$ & $<0.01$ & $<0.10$ & 0.15 & $<0.10$ & $<0.03$ & 0.10 & $0.15 \pm 0.01$ & 0.8 \\
\hline 02 & $6.52 \pm 0.20$ & $12.3 \pm 0.4$ & $6.1 \pm 0.2$ & $6.1 \pm 0.2$ & nd & 0.02 & 0.15 & 0.18 & $<0.01$ & 1.00 & 0.68 & 1.55 & $<0.03$ & $<0.10$ & $0.22 \pm 0.01$ & $<0.7$ \\
\hline 03 & $7.86 \pm 0.08$ & $106.2 \pm 1.7$ & $53.1 \pm 0.9$ & $63.4 \pm 3.5$ & nd & $0.08 \pm 0.01$ & 0.56 & 2.77 & $<0.01$ & $0.82 \pm 0.01$ & $6.03 \pm 0.01$ & 0.19 & $<0.03$ & $1.10 \pm 0.01$ & $13.67 \pm 0.01$ & 38.7 \\
\hline 04 & $7.40 \pm 0.06$ & $106.7 \pm 1.0$ & $53.3 \pm 0.4$ & $69.5 \pm 8.9$ & nd & 0.08 & $0.60 \pm 0.01$ & 2.66 & $<0.01$ & 0.90 & $5.94 \pm 0.01$ & $0.21 \pm 0.01$ & $<0.03$ & $1.16 \pm 0.01$ & $14.35 \pm 0.06$ & 40.6 \\
\hline 05 & $6.76 \pm 0.11$ & $85.5 \pm 2.5$ & $42.8 \pm 1.3$ & $48.0 \pm 1.8$ & nd & 0.14 & $1.30 \pm 0.01$ & $2.24 \pm 0.01$ & $<0.01$ & 0.43 & $6.78 \pm 0.02$ & 2.78 & $<0.03$ & $1.83 \pm 0.04$ & $5.81 \pm 0.08$ & 22.0 \\
\hline 06 & $8.13 \pm 0.04$ & $118.4 \pm 1.2$ & $59.1 \pm 0.5$ & $75.6 \pm 3.5$ & nd & 0.06 & $<0.10$ & 0.10 & $<0.01$ & 0.17 & $17.46 \pm 0.01$ & $1.71 \pm 0.01$ & $<0.03$ & 0.25 & $7.77 \pm 0.02$ & 20.4 \\
\hline 07 & $7.87 \pm 0.02$ & $248.3 \pm 4.0$ & $125.8 \pm 1.1$ & $167.6 \pm 1.8$ & nd & 0.05 & 0.70 & $2.64 \pm 0.01$ & $<0.01$ & 0.65 & 0.98 & 0.54 & $<0.03$ & $16.31 \pm 0.06$ & $28.17 \pm 0.04$ & 137.5 \\
\hline 08 & $7.29 \pm 0.03$ & $51.1 \pm 0.1$ & $25.4 \pm 0.2$ & $18.4 \pm 0.1$ & nd & 0.03 & 0.98 & 6.26 & $<0.01$ & 0.50 & 0.89 & $1.98 \pm 0.02$ & $<0.03$ & $1.81 \pm 0.02$ & $3.52 \pm 0.04$ & 16.2 \\
\hline 09 & $6.27 \pm 0.13$ & $133.2 \pm 0.3$ & $16.6 \pm 0.1$ & $17.4 \pm 1.8$ & nd & 0.03 & 0.34 & 2.31 & $<0.01$ & 0.15 & 1.00 & 1.44 & $<0.03$ & 1.40 & 1.86 & 10.4 \\
\hline 10 & $7.19 \pm 0.03$ & $136.7 \pm 0.4$ & $93.4 \pm 0.1$ & $12.3 \pm 0.2$ & nd & $<0.02$ & $10.96 \pm 0.02$ & $63.05 \pm 0.13$ & $<0.01$ & $<0.10$ & $7.59 \pm 0.01$ & 0.31 & $<0.03$ & $5.90 \pm 0.02$ & $13.00 \pm 0.05$ & 56.8 \\
\hline 11 & $7.92 \pm 0.06$ & $161.8 \pm 0.5$ & $81.5 \pm 0.2$ & $90.0 \pm 3.5$ & nd & 0.08 & 2.31 & $5.44 \pm 0.01$ & $<0.01$ & 0.24 & 7.21 & 1.87 & $<0.03$ & $5.01 \pm 0.03$ & $15.98 \pm 0.10$ & 60.5 \\
\hline 12 & $7.21 \pm 0.04$ & $202.9 \pm 3.8$ & $101.6 \pm 1.5$ & $117.6 \pm 1.8$ & nd & 0.25 & 3.26 & 0.44 & $<0.01$ & $1.78 \pm 0.03$ & $10.32 \pm 0.01$ & 2.45 & $<0.03$ & $5.70 \pm 0.01$ & $20.50 \pm 0.30$ & 74.7 \\
\hline 13 & $8.00 \pm 0.02$ & $181.9 \pm 0.6$ & $91.5 \pm 0.2$ & $110.4 \pm 1.0$ & nd & 0.10 & 1.78 & $2.53 \pm 0.01$ & $<0.01$ & $1.04 \pm 0.02$ & $5.07 \pm 0.01$ & $1.26 \pm 0.01$ & $<0.03$ & $7.78 \pm 0.05$ & $18.47 \pm 0.07$ & 78.2 \\
\hline 14 & $8.49 \pm 0.01$ & $295.3 \pm 1.2$ & $148.9 \pm 0.4$ & $190.1 \pm 6.1$ & 3.0 & 0.04 & $1.61 \pm 0.01$ & $4.56 \pm 0.01$ & 0.01 & $0.88 \pm 0.01$ & $1.37 \pm 0.01$ & 0.86 & $<0.03$ & $18.33 \pm 0.01$ & $32.56 \pm 0.03$ & 156.8 \\
\hline 15 & $8.11 \pm 0.03$ & $233.7 \pm 0.6$ & $116.4 \pm 0.4$ & $124.7 \pm 3.5$ & nd & 0.38 & $2.61 \pm 0.01$ & $<0.10$ & $<0.01$ & $12.06 \pm 0.03$ & $33.30 \pm 0.07$ & $1.20 \pm 0.09$ & $<0.03$ & 0.44 & $16.17 \pm 0.09$ & 42.2 \\
\hline 16 & $7.80 \pm 0.02$ & $234.0 \pm 2.0$ & $117.0 \pm 1.1$ & $121.6 \pm 1.8$ & nd & 0.05 & $3.39 \pm 0.01$ & $20.68 \pm 0.02$ & 0.04 & 0.70 & 7.28 & 0.91 & $<0.03$ & $8.49 \pm 0.10$ & $26.38 \pm 0.02$ & 100.8 \\
\hline 17 & $8.79 \pm 0.03$ & $217.0 \pm 1.0$ & $107.8 \pm 0.3$ & $128.8 \pm 0.8$ & 3.0 & 0.22 & 0.64 & 2.88 & $<0.01$ & 0.54 & $35.71 \pm 0.06$ & 0.46 & $<0.03$ & $2.53 \pm 0.01$ & $8.83 \pm 0.02$ & 32.5 \\
\hline 18 & $8.18 \pm 0.05$ & $284.7 \pm 1.5$ & $143.1 \pm 0.5$ & $159.5 \pm 6.1$ & nd & 0.06 & $3.84 \pm 0.02$ & $16.39 \pm 0.08$ & $<0.01$ & $2.16 \pm 0.02$ & $8.90 \pm 0.01$ & $0.62 \pm 0.01$ & $<0.03$ & 9.89 & $32.68 \pm 0.13$ & 122.3 \\
\hline 19 & $8.44 \pm 0,05$ & $333.7 \pm 0.6$ & $166.3 \pm 0.3$ & $218.8 \pm 3.5$ & 3.0 & 0.03 & $1.40 \pm 0.01$ & $3.18 \pm 0.02$ & 0.01 & 0.19 & $2.19 \pm 0.01$ & $0.86 \pm 0.01$ & $<0.03$ & $20.52 \pm 0.03$ & $37.12 \pm 0.13$ & 177.2 \\
\hline 20 & $8.19 \pm 0.03$ & $360.0 \pm 4.6$ & $180.2 \pm 2.2$ & $256.6 \pm 1.8$ & nd & 0.04 & $0.90 \pm 0.01$ & $1.02 \pm 0.01$ & $<0.01$ & $0.68 \pm 0.01$ & 1.61 & 0.83 & $<0.03$ & $26.14 \pm 0.05$ & $41.17 \pm 0.08$ & 210.5 \\
\hline 21 & $7.76 \pm 0.06$ & $326.3 \pm 7.4$ & $163.2 \pm 3.6$ & $228.0 \pm 4.7$ & nd & $<0.02$ & 1.74 & $5.53 \pm 0.03$ & 0.01 & $0.25 \pm 0.01$ & $1.18 \pm 0.01$ & 0.37 & $<0.03$ & $21.41 \pm 0.03$ & $37.78 \pm 0.08$ & 182.5 \\
\hline 22 & $7.44 \pm 0.02$ & $492.0 \pm 0.6$ & $247.0 \pm 1.1$ & $325.1 \pm 3.5$ & nd & $0.16 \pm 0.01$ & $1.56 \pm 0.01$ & $1.74 \pm 0.02$ & $<0.01$ & $1.91 \pm 0.01$ & $38.27 \pm 0.18$ & $38.24 \pm 0.16$ & $<0.03$ & $13.29 \pm 0.19$ & $32.28 \pm 0.16$ & 135.4 \\
\hline 23 & $5.53 \pm 0.01$ & $718.0 \pm 5.0$ & $360.2 \pm 2.0$ & $398.7 \pm 2.0$ & nd & $0.11 \pm 0.01$ & $20.80 \pm 0.06$ & $5.26 \pm 0.10$ & $<0.01$ & $29.10 \pm 0.11$ & $11.18 \pm 0.02$ & $0.89 \pm 0.06$ & $<0.03$ & $3.61 \pm 0.01$ & $157.37 \pm 0.34$ & 407.9 \\
\hline 24 & $8.89 \pm 0.05$ & $1129 \pm 8$ & $566.4 \pm 1.6$ & $708.4 \pm 1.1$ & 30.2 & $1.22 \pm 0.04$ & $51.19 \pm 0.10$ & $2.81 \pm 0.08$ & $<0.01$ & $25.73 \pm 0.06$ & $174.28 \pm 0.04$ & $12.03 \pm 0.08$ & $<0.03$ & $84.34 \pm 0.22$ & $170.69 \pm 0.16$ & 773.6 \\
\hline 25 & $6.42 \pm 0.03$ & $2620 \pm 10$ & $1308 \pm 5$ & $1294.1 \pm 2.5$ & nd & $0.56 \pm 0.01$ & $25.79 \pm 0.01$ & $<0.10$ & $<0.01$ & $4.17 \pm 0.01$ & $553.12 \pm 0.74$ & $30.51 \pm 0.27$ & $<0.03$ & $22.02 \pm 0.88$ & $139.88 \pm 2.32$ & 440.0 \\
\hline 26 & $5.46 \pm 0.02$ & $1110 \pm 11$ & $551.0 \pm 1.6$ & $220.8 \pm 1.1$ & nd & $0.58 \pm 0.03$ & $50.86 \pm 0.48$ & $3.24 \pm 0.14$ & $<0.01$ & $420.71 \pm 2.77$ & $33.79 \pm 0.05$ & $2.37 \pm 0.04$ & $<0.03$ & $47.79 \pm 0.90$ & $173.44 \pm 2.77$ & 629.9 \\
\hline 27 & $8.25 \pm 0.03$ & $245.0 \pm 3.6$ & $124.5 \pm 2.5$ & $104.3 \pm 2.0$ & nd & 0.04 & $6.89 \pm 0.03$ & $3.10 \pm 0.01$ & $<0.01$ & $20.85 \pm 0.06$ & $7.90 \pm 0.01$ & 0.84 & $<0.03$ & $6.22 \pm 0.06$ & $30.68 \pm 0.03$ & 102.2 \\
\hline
\end{tabular}

Braz. Arch. Biol. Technol. v.59: e16160111, Jan/Dec 2016 
Table 6. Results for cations determined by ICP OES, CVG-ICP OES and ICP-MS ( $\mathrm{n}=3$ ).

\begin{tabular}{|c|c|c|c|c|c|c|c|c|c|c|c|c|c|c|c|c|c|}
\hline sample & $\underset{\left(\mu \mathrm{g} \mathrm{L} \mathbf{L}^{-1}\right)}{\mathrm{Al}}$ & $\underset{\left(\mu \mathrm{g} \mathrm{L^{-1 }}\right)}{\mathbf{A s}}$ & $\begin{array}{c}\mathbf{B a} \\
\left(\mu \mathbf{g ~ L}^{-1}\right)\end{array}$ & $\underset{\left(\mu \mathrm{g} \mathrm{L^{-1 }}\right)}{\mathbf{C d}}$ & $\underset{\left(\mu \mathrm{g} \mathrm{L^{-1 }}\right)}{\mathbf{C r}}$ & $\underset{\left(\mu \mathrm{g} \mathrm{L}^{-1}\right)}{\mathrm{Cu}}$ & $\begin{array}{c}\mathbf{F e} \\
\left(\mu \mathrm{g} \mathrm{L^{-1 }}\right)\end{array}$ & $\underset{\left(\mu \mathrm{g} \mathrm{L^{-1 }}\right)}{\mathbf{H g}}$ & $\begin{array}{c}\mathbf{L i} \\
\left(\mu \mathrm{g} \mathbf{L}^{-1}\right)\end{array}$ & $\underset{\left(\mu \mathrm{g} \mathrm{L}^{-1}\right)}{\mathrm{Mn}}$ & $\begin{array}{c}\mathrm{Ni} \\
\left(\mu \mathrm{g} \mathrm{L^{-1 }}\right)\end{array}$ & $\begin{array}{c}\mathbf{P b} \\
\left(\mu \mathrm{g} \mathrm{L}^{-1}\right)\end{array}$ & $\underset{\left(\mu \mathrm{g} \mathrm{L^{-1 }}\right)}{\mathbf{S b}}$ & $\begin{array}{c}\mathrm{Se} \\
\left(\mu \mathrm{g} \mathrm{L}^{-1}\right)\end{array}$ & $\underset{\left(\mu g L^{-1}\right)}{S r}$ & $\underset{\left(\mu \mathrm{g} \mathrm{L} \mathrm{L}^{-1}\right)}{\mathbf{V}}$ & $\underset{(\mu \mathrm{gn} \mathrm{L}}{\mathrm{Zn}}$ \\
\hline Legislation & ${ }^{(2)} 200 \max$ & (2) 10 max. & (2) 700 max. & (2) 3 max. & (2) 50 max. & (2) 1000 max. & ---- & (2) 1.0 max. & (1) $10 \mathrm{~min}$. & (2) 500 max. & (2) 20 max. & ${ }^{(2)} 10 \max$. & (2) 5 max. & $\begin{array}{l}\text { (1) } 6 \text { min. } \\
\text { (2) } 10 \text { max. }\end{array}$ & ---- & (1) $30 \mathrm{~min}$. & ${ }^{(3)} 500$ max. \\
\hline 01 & $<10$ & $<1.0$ & 5 & $<1.0$ & $<1.0$ & $<10$ & $<10$ & $<0.2$ & $<10$ & $1.9 \pm 0.1$ & $<10$ & $<1.0$ & $<1.0$ & $<1.0$ & $<5$ & $<10$ & $<10$ \\
\hline 02 & $<10$ & $<1.0$ & $58 \pm 3$ & $<1.0$ & $<1.0$ & $<10$ & $<10$ & $<0.2$ & $<10$ & $1.1 \pm 0.1$ & $<10$ & $<1.0$ & $<1.0$ & $<1.0$ & $<5$ & $<10$ & $<10$ \\
\hline 03 & $<10$ & $<1.0$ & $<1$ & $<1.0$ & $<1.0$ & $<10$ & $<10$ & $<0.2$ & $<10$ & $<1$ & $<10$ & $<1.0$ & $<1.0$ & $<1.0$ & $<5$ & $10 \pm 1$ & $<10$ \\
\hline 04 & $<10$ & $<1.0$ & $<1$ & $<1.0$ & $<1.0$ & $<10$ & $<10$ & $<0.2$ & $<10$ & $<1$ & $<10$ & $<1.0$ & $<1.0$ & $<1.0$ & $<5$ & $10 \pm 1$ & $<10$ \\
\hline 05 & $<10$ & $<1.0$ & $76 \pm 5$ & $<1.0$ & $<1.0$ & $<10$ & $<10$ & $<0.2$ & $<10$ & $<1$ & $<10$ & $<1.0$ & $<1.0$ & $<1.0$ & $137 \pm 5$ & $<10$ & $<10$ \\
\hline 06 & $<10$ & $<1.0$ & 1 & $<1.0$ & $4.9 \pm 0.1$ & $<10$ & $<10$ & $<0.2$ & $<10$ & $<1$ & $<10$ & $<1.0$ & $<1.0$ & $<1.0$ & $333 \pm 10$ & $<10$ & $<10$ \\
\hline 07 & $<10$ & $<1.0$ & $16 \pm 1$ & $<1.0$ & $<1$ & $<10$ & $<10$ & $<0.2$ & $<10$ & $<1$ & $<10$ & $<1.0$ & $<1.0$ & $<1.0$ & $<5$ & $<10$ & $<10$ \\
\hline 08 & $<10$ & $<1.0$ & $80 \pm 4$ & $<1.0$ & $1.9 \pm 0.1$ & $<10$ & $<10$ & $<0.2$ & $<10$ & $8.9 \pm 0.2$ & $<10$ & $<1.0$ & $<1.0$ & $<1.0$ & $33 \pm 2$ & $<10$ & $<10$ \\
\hline 09 & $<10$ & $<1.0$ & $63 \pm 2$ & $<1.0$ & $<1$ & $<10$ & $<10$ & $<0.2$ & $<10$ & $2.0 \pm 0.1$ & $<10$ & $<1.0$ & $<1.0$ & $<1.0$ & 7 & $<10$ & $<10$ \\
\hline 10 & $<10$ & $<1.0$ & $100 \pm 5$ & $<1.0$ & $<1$ & $<10$ & $<10$ & $<0.2$ & $<10$ & $4.3 \pm 0.2$ & $<10$ & $<1.0$ & $<1.0$ & $<1.0$ & $56 \pm 5$ & $<10$ & $14 \pm 1$ \\
\hline 11 & $<10$ & $<1.0$ & 7 & $<1.0$ & $2.3 \pm 0.1$ & $<10$ & $<10$ & $<0.2$ & $<10$ & $<1$ & $<10$ & $<1.0$ & $<1.0$ & $<1.0$ & $86 \pm 3$ & $21 \pm 1$ & $<10$ \\
\hline 12 & $<10$ & $<1.0$ & $19 \pm 1$ & $<1.0$ & $<1$ & $<10$ & $<10$ & $<0.2$ & $<10$ & $<1$ & $<10$ & $<1.0$ & $<1.0$ & $<1.0$ & $128 \pm 12$ & $<10$ & $<10$ \\
\hline 13 & $<10$ & $<1.0$ & $75 \pm 2$ & $<1.0$ & $1.5 \pm 0.1$ & $<10$ & $<10$ & $<0.2$ & $<10$ & $2.1 \pm 0.1$ & $<10$ & $<1.0$ & $<1.0$ & $<1.0$ & $100 \pm 4$ & $<10$ & $22 \pm 1$ \\
\hline 14 & $<10$ & $<1.0$ & $22 \pm 1$ & $<1.0$ & $<1$ & $<10$ & $<10$ & $<0.2$ & $<10$ & $<1$ & $<10$ & $<1.0$ & $<1.0$ & $<1.0$ & $<5$ & $<10$ & $<10$ \\
\hline 15 & $<10$ & $1.1 \pm 0.1$ & 6 & $<1.0$ & $<1$ & $<10$ & $<10$ & $<0.2$ & $<10$ & $<1$ & $<10$ & $<1.0$ & $<1.0$ & $<1.0$ & $316 \pm 13$ & $<10$ & $<10$ \\
\hline 16 & $<10$ & $<1.0$ & 3 & $<1.0$ & $<1$ & $<10$ & $<10$ & $<0.2$ & $<10$ & $<1$ & $<10$ & $<1.0$ & $2.3 \pm 0.2$ & $<1.0$ & $121 \pm 8$ & $19 \pm 1$ & $<10$ \\
\hline 17 & $<10$ & $2.4 \pm 0.1$ & 1 & $<1.0$ & $<1$ & $<10$ & $<10$ & $<0.2$ & $<10$ & $<1$ & $<10$ & $<1.0$ & $<1.0$ & $3.4 \pm 0.2$ & $30 \pm 5$ & $150 \pm 5$ & $<10$ \\
\hline 18 & $<10$ & $<1.0$ & 1 & $<1.0$ & $<1$ & $<10$ & $<10$ & $<0.2$ & $<10$ & $<1$ & $<10$ & $<1.0$ & $<1.0$ & $<1.0$ & $62 \pm 5$ & $24 \pm 2$ & $<10$ \\
\hline 19 & $<10$ & $<1.0$ & $34 \pm 2$ & $<1.0$ & $<1$ & $<10$ & $<10$ & $<0.2$ & $<10$ & $<1$ & $<10$ & $<1.0$ & $<1.0$ & $<1.0$ & $<5$ & $<10$ & $<10$ \\
\hline 20 & $<10$ & $<1.0$ & $37 \pm 4$ & $<1.0$ & $<1$ & $<10$ & $<10$ & $<0.2$ & $<10$ & $<1$ & $<10$ & $<1.0$ & $<1.0$ & $<1.0$ & $25 \pm 2$ & $<10$ & $<10$ \\
\hline 21 & $<10$ & $<1.0$ & 9 & $<1.0$ & $<1$ & $<10$ & $<10$ & $<0.2$ & $<10$ & $<1$ & $<10$ & $<1.0$ & $<1.0$ & $<1.0$ & $<5$ & $<10$ & $<10$ \\
\hline 22 & $20 \pm 0.2$ & $<1.0$ & $386 \pm 5$ & $<1.0$ & $<1$ & $<10$ & $<10$ & $<0.2$ & $10 \pm 1$ & $1.1 \pm 0.1$ & $<10$ & $<1.0$ & $1.0 \pm 0.1$ & $<1.0$ & $35 \pm 1$ & $<10$ & $<10$ \\
\hline 23 & $13 \pm 0.5$ & $<1.0$ & $26 \pm 1$ & $<1.0$ & $1.3 \pm 0.1$ & $<10$ & $<10$ & $<0.2$ & $<10$ & $<1$ & $<10$ & $<1.0$ & $<1.0$ & $1.5 \pm 0.1$ & $600 \pm 15$ & $10 \pm 1$ & $<10$ \\
\hline 24 & $10 \pm 0.1$ & $6.1 \pm 0.2$ & 2 & $<1.0$ & $<1$ & $<10$ & $<10$ & $<0.2$ & $387 \pm 8$ & 0.9 & $<10$ & $<1.0$ & $<1.0$ & $6.4 \pm 0.3$ & $1127 \pm 20$ & $10 \pm 1$ & $<10$ \\
\hline 25 & $30 \pm 1$ & $1.4 \pm 0.1$ & 2 & $<1.0$ & $<1$ & $<10$ & $<10$ & $<0.2$ & $863 \pm 10$ & $155.6 \pm 5$ & $<10$ & $<1.0$ & $<1.0$ & $<1.0$ & $959 \pm 12$ & $10 \pm 1$ & $<10$ \\
\hline 26 & $14 \pm 0.1$ & $2.4 \pm 0.1$ & $15 \pm 1$ & $<1.0$ & $1.3 \pm 0.1$ & $<10$ & $10 \pm 1$ & $<0.2$ & $57 \pm 5$ & $<1$ & $<10$ & $<1.0$ & $<1.0$ & $<1.0$ & $2364 \pm 18$ & $11 \pm 1$ & $<10$ \\
\hline 27 & $10 \pm 0.3$ & $<1.0$ & $74 \pm 1$ & $<1.0$ & $<1$ & $<10$ & $21 \pm 1$ & $<0.2$ & $<10$ & $<1$ & $<10$ & $<1.0$ & $<1.0$ & $1.2 \pm 0.1$ & $246 \pm 5$ & $<10$ & $37 \pm 2$ \\
\hline
\end{tabular}

nd: notdetected; legislation: Portaria $\mathrm{N}^{\circ} 540$ de 18/12/2014 ${ }^{1}, \mathrm{RDC} \mathrm{N}^{\circ} 274$ de 22/09/2005 ${ }^{2}$, Portaria $\mathrm{N}^{\circ} 2914$ de 12/12/2011 ${ }^{3}$. 


\section{CONCLUSIONS}

The present study reveals that, in general, the majority of parameters determined in commercial bottled mineral waters from markets in CuritibaPR-Brazil are below limits specified by Brazilian legislation. Only one sample was detected as having a high concentration of $\mathrm{NO}_{3}{ }^{-}$, indicating microbiological contamination; some results for $\mathrm{NO}_{2}^{-}$may also reflect the same contamination. Improvements in monitoring throughout the process of filling and points of sale of the samples, with the aim of securing the microbiological quality of bottled mineral waterssold in the region under study may be needed. The comparison of labelled composition to analytical results highlights a difference for mostelements, but it should be noted that intrinsic instabilityas well asother factors such assorption of components onto container surfaces as well as the length of time spent on the shelf, care during transport, and the ambient storage temperature may alter the composition; perhaps a "best before date" could eliminate such discrepancies. In such cases,a furtherstudy of thestability andinteractionwith thepackaging should be performed. Although a perfect division of samples from PR State is not achieved according to their mineral composition, PCA scores clearly delineate the imported samples from those from other states.

\section{ACKNOWLEDGEMENTS}

The authors are thankfulto Conselho Nacional de Pesquisas e Desenvolvimento Tecnológico (CNPq, Brazil) for thescholarshiptoDasio R. De Oliveira Júnior andto Financiadora de Estudos e Projetos (FINEP, Brazil) for financial support (Rede de Monitoramento Ambiental - Rema/Sibratec).

\section{REFERENCES}

Astel, A., Michalski, R., Łyko, A., Jablońska-Czapla, M., Bigus, K., Szopa, S., Kwiecińska, A. (2014). Characterization of bottled mineral waters marketed in Poland using hierarchical clusters analysis. $J$. Geo. Exploration, 143, 136-145.

Decreto - Lei No 7.841 de 08/08/1945: Código de Águas Minerais. D.O.U. 20/08/1945, Seção 1. Brazil, 1945.

Dinelli, E., Lima, A., Albanese, S., Birke, S., Cicchella, D., Giaccio, L., Valera, P., De Vivo, B. (2012). Comparative study between bottled mineral and tap water in Italy. J. Geo. Exploration, 112, 368-389.
Dias, A. M., Dubow, M., Cardoso, I. P., Suzuki, L. E. A. S., Faria, L. C., Milani, I. C. B. Características físico-química de águas minerais das regiões sul e sudeste do Brasil. In: Congresso de Iniciação Científica da UFPel., 2012, Pelotas, RS. Anais do XXI Congresso de Iniciação Científica da UFPel. Pelotas: Universidade Federal de Pelotas, RS, 2012, p. 1-4.

Dos Santos, J.S., Dos Santos, M. L., Oliveira, E. (2008). Study of metal and trace element mobilization in aquatic environments of brazilian semi-arid zones applying principal component analysis. Quím. Nova, 31 (5), 1107-1111.

Dos Santos, E. J., Baika, L. M., Herrmann, A. B., Kulik, S., Sato, C. S., Dos Santos, A. B., Curitus, A. J. (2012). Fast assessment of mineral constituents in grass by inductively coupled plasma optical emission spectrometry. Braz. Arch. Biol. Technol., 55 (3), 457-464.

Felipe-Sotelo, M., Henshall-Bell, E. R., Evans, N. D. M., Read, D. (2015). Comparison of the chemical composition of British and Continental European bottled waters by multivariate analysis. J. Food and Comp. Anal., 39, 33-42.

Godoy, J. M., Amaral, E. C. S, Godoy, M. L. D. P. (2001). Natural radionuclides in Brazilian mineral water and consequente doses to the population. $J$. Environ. Radioactivity, 53, 175-182.

Ikem, A., Odueyungboo, S., Egiebor, N. O., Nyavor, K. (2002). Chemical quality of bottled waters from three cities in eastern Alabama. Sci. TotalEnviron., $285,165-175$.

Morgano, M. A., Schatti, A. C., Enriques, H. A., Mantovani, D. M. B. (2002). Avaliação físicoquímica de águas minerais comercializadas na região de Campinas, SP. Ciênc.Tecnol. Aliment., 22(3), 239-243.

Miller, J. N., Miller, J. C. Statistics and Chemometries for Analytical Chemistru. $5^{\text {th }}$ ed. Edinburgh: Person Education; 2000.

Portaria $\quad \mathrm{N}^{\mathrm{o}} \quad 540 \quad$ de $18 / 12 / 2014$ : establishesminimumlimits ofnoteworthyelementsfor the classification ofmineral waters - DNPM, Brazil, 2014.

Portaria $N^{\circ} 2914$ de 12/12/2011: Sets forth the proceduresofcontroland surveillance ofwater qualityfor human consumption andits potability standards, Ministry of Health,Brazil, 2011.

RDC $\mathrm{N}^{\circ} 274$ de 22/09/2005:approves the Thechnical regulations for water bottled and ices - ANVISA, Brazil, 2005.

Standard Methods for the Examination of Water and Wastewater, 22 ${ }^{\mathrm{a}}$ Edition, 2012.

Saleh, M. A., Ewane, E., Jones, J., Wilson, B. L. (2001). Chemical evaluation of commercial bottled drinking water from Egypt.J. Foodand Comp. Anal., 14, 127-152. 
Silva Pereira, M. S.; Dos Reis, B. F. (2012). Spectrophotometric aluminium determination in high salts concentration solution used in hemodyalisisemploingpreconcentration in flow injection. Quim. Nova, 25 (6), 931-934.
Zan, R. A., Vieira, F. G., Bavaresco, M. F., Meneguetti, D. U. O. (2013). Quality assessment of mineral Waters in cities of commercially Jamari Valley, western Amazon, Brazil-Rondonia. Rev. SaúdePúbl. Santa Cat., 6(4), 19-26. 


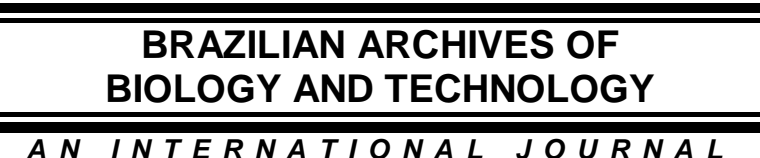

\section{Erratum}

In Article "Chemical quality of bottled mineral waters from markets of Curitiba-PRBrazil", with the number of DOI: http://dx.doi.org/10.1590/1678-4324-2016150111, published in journal Brazilian Archives of Biology and Technology, vol. 59, the 01 page. That read:

"Éder José dos Santos ${ }^{1 *}$,Dasio Roberto de Oliveira Junior", Amanda Beatriz Hermann $^{1}$,Ralph Edwatd Sturgeon ${ }^{2}$.

${ }^{1}$ Instituto de Tecnologia do Paraná - TECPAR - Centro de Tecnologia em Saúde e Meio Ambiente, Curitiba, Paraná, Brasil; ${ }^{2}$ Measurement Science and Standards, NationalResearchCouncil Canada, Ottawa, Canada."

Read:

“Éder José dos Santos" ${ }^{*}$, Dasio Roberto de Oliveira Junior", Amanda Beatriz Hermann ${ }^{1}$, Ralph Edward Sturgeon ${ }^{2}$.

${ }^{1}$ Instituto de Tecnologia do Paraná - TECPAR - Centro de Tecnologia em Saúde e Meio Ambiente, Curitiba, Paraná, Brasil; ${ }^{2}$ Measurement Science and Standards, National Research Council Canada, Ottawa, Canada."

In Article "Chemical quality of bottled mineral waters from markets of Curitiba-PRBrazil", with the number of DOI: http://dx.doi.org/10.1590/1678-4324-2016150111, published in journal Brazilian Archives of Biology and Technology, vol. 59, the 02 page.

That read:

"In Brazil, in accordance with RDC Resolution No. 274/2005 of the Ministry of Health, mineral water is "water obtaineddirectly fromnaturalorgroundwater extractionsources". Concern overthe qualityof mineral wateron the marketis highlightedin several articles devoted to this subject.Ikem et al. investigated the chemical quality of twenty-five bottled waters from cities in the state of Alabama, USA, through a one-wayparametricanalysisof variance(ANOVA) and showed thatseveralsamplesavailable on the markethadphysical-chemical parameters ( $\mathrm{pH}$ and conductivity) as well as essential and non-essential elements exceeding the EU and US EPA drinking water standards (Ikem et al., 2002)."

Read:

"In Brazil, in accordance with RDC Resolution No. 274/2005 of the Ministry of Health, mineral water is "water obtained directly from natural or ground water extraction sources". Concern over the quality of mineral water on the market is highlighted in several articles devoted to this subject. Ikem et al. investigated the chemical quality of twenty-five bottled waters from cities in the state of Alabama, USA, through a one-way parametric analysis of variance(ANOVA) and showed that several samplesavailable on the market had physical-chemical parameters ( $\mathrm{pH}$ and conductivity) as well as essential and non-essential elements exceeding the EU and US EPA drinking water standards (Ikem et al., 2002)." 
In Article "Chemical quality of bottled mineral waters from markets of Curitiba-PRBrazil", with the number of DOI: http://dx.doi.org/10.1590/1678-4324-2016150111, published in journal Brazilian Archives of Biology and Technology, vol. 59, the 02 page.

That read:

"In these studies, the concentrations ofinorganicions as well as parameterssuch aspH, electrolyticconductivity and inorganicand total organiccarbon were determined. For thispurpose, the main analytical techniques employed were ion chromatography (IC), inductively coupled plasma optical emission spectrometry (ICP OES) and inductively coupled plasma mass spectrometry (ICPMS). In Brazil, studies have also highlightedconcern over thequality and compositionof bottled mineral waters available on the market. Godoy et al. investigated the natural radionuclides ${ }^{228} \mathrm{Ra}$, ${ }^{226} \mathrm{Ra}$ and ${ }^{210} \mathrm{~Pb}$ in Brazilian bottled mineral waters (Godoy et al., 2001).”

Read:

"In these studies, the concentrations of inorganicions as well as parameters such asp $\mathrm{H}$, electrolytic conductivity and inorganic and total organic carbon were determined. For this purpose, the main analytical techniques employed were ion chromatography (IC), inductively coupled plasma optical emission spectrometry (ICP OES) and inductively coupled plasma mass spectrometry (ICP-MS). In Brazil, studies have also highlighted concern over the quality and composition of bottled mineral waters available on the market. Godoy et al. investigated the natural radionuclides ${ }^{228} \mathrm{Ra},{ }^{226} \mathrm{Ra}$ and ${ }^{210} \mathrm{~Pb}$ in Brazilian bottled mineral waters (Godoy et al., 2001)."

In Article "Chemical quality of bottled mineral waters from markets of Curitiba-PRBrazil", with the number of DOI: http://dx.doi.org/10.1590/1678-4324-2016150111, published in journal Brazilian Archives of Biology and Technology, vol. 59, the 03 page.

That read:

Table 1. ICP OES, CVG-ICP OES and ICP-MS instrumental parameters.

\begin{tabular}{|c|c|c|c|}
\hline \multicolumn{2}{|r|}{ ICP OES } & CVG-ICP OES & ICP-MS \\
\hline Radiofrequency & $40 \mathrm{MHz}$ & $40 \mathrm{MHz}$ & $27.12 \mathrm{MHz}$ \\
\hline Forward power & $1.25 \mathrm{~kW}$ & $1.2 \mathrm{~kW}$ & $1.4 \mathrm{~kW}$ \\
\hline Plasma gasflow rate & $15.0 \mathrm{~L} \mathrm{~min}^{-1}$ & 15.0 $\mathrm{L} \mathrm{min}^{-1}$ & $18.0 \mathrm{~L} \mathrm{~min}^{-1}$ \\
\hline Auxiliarygasflow rate & $1.5 \mathrm{~L} \mathrm{~min}^{-1}$ & $1.5 \mathrm{~L} \mathrm{~min}^{-1}$ & $1.8 \mathrm{~L} \mathrm{~min}^{-1}$ \\
\hline Sheathgasflow & ---------------- & ---------------- & $0.21 \mathrm{~L} \mathrm{~min}^{-1}$ \\
\hline Carrier gas flow rate & 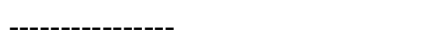 & $120 \mathrm{~mL} \mathrm{~min}^{-1}$ & ---------------- \\
\hline Nebulizerpressure & $180 \mathrm{kPa}$ & ---------------- & ---------------- \\
\hline Nebulizertype & Concentricglass $\mathrm{K}$ & 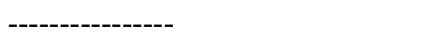 & ------- \\
\hline Spray chamber & Standard Axial Varian & Standard Axial Varian & ---------------- \\
\hline Replicateread time & $15 \mathrm{~s}$ with 4 replicates & $15 \mathrm{~s}$ with 4 replicates & $20 \mathrm{~s}$ with 8 replicates \\
\hline Torchtype & $1.8 \mathrm{~mm}$ I.D. alumina injector tube & Quartz for axial view & Quartz \\
\hline $\begin{array}{l}\mathrm{NaBH}_{4} \text { concentration } \\
\mathrm{HCl} \text { concentration }\end{array}$ & ----------------- & $0.3 \%(\mathrm{~m} / \mathrm{v})$ in $0.4 \%, \mathrm{~m} / \mathrm{v}, \mathrm{NaOH}$ & ----------------- \\
\hline $\begin{array}{l}\text { Analytical lines / } \\
\text { isotopes (ICP-MS) }\end{array}$ & $\begin{array}{l}\mathrm{Al}: 396.152 \mathrm{~nm}, \mathrm{Ba}: 455.403 \mathrm{~nm}, \\
\mathrm{Cd}: 214.439 \mathrm{~nm}, \mathrm{Cr}: 267.716 \mathrm{~nm}, \\
\mathrm{Cu}: 327.395 \mathrm{~nm} \text {; Fe: } 238.204 \mathrm{~nm}, \\
\mathrm{Li}: 610.365 \mathrm{~nm}, \mathrm{Mn}: 257.610 \mathrm{~nm}, \\
\mathrm{Ni}: 231.604 \mathrm{~nm}, \mathrm{Sr}: 421.552 \mathrm{~nm}, \\
\text { V: } 292.401 \mathrm{~nm}, \mathrm{Zn}: 213.857 \mathrm{~nm}\end{array}$ & $\mathrm{Hg}: 252.652 \mathrm{~nm}$ & $\begin{array}{l}{ }^{75} \mathrm{As},{ }^{121} \mathrm{Sb}, \quad{ }^{206,207,208} \mathrm{~Pb} \\
\text { and }^{78} \mathrm{Se}\end{array}$ \\
\hline Collisionalgas CRI & ------------------ & ------------------ & $\mathrm{H}_{2}\left({ }^{78} \mathrm{Se}\right)$ \\
\hline Internal standard & ---------------- & ---------------- & ${ }^{89} \mathrm{Y},{ }^{115} \mathrm{In}$ \\
\hline
\end{tabular}

Read:

Table 1. ICP OES, CVG-ICP OES and ICP-MS instrumental parameters.

\begin{tabular}{|c|c|c|c|}
\hline & ICP OES & CVG-ICP OES & ICP-MS \\
\hline Radiofrequencr & $40 \mathrm{MHz}$ & $40 \mathrm{MHz}$ & $27.12 \mathrm{MHz}$ \\
\hline
\end{tabular}




\begin{tabular}{|c|c|c|c|}
\hline Forward power & $1.25 \mathrm{~kW}$ & $1.2 \mathrm{~kW}$ & $1.4 \mathrm{~kW}$ \\
\hline Plasma gas flow rate & $15.0 \mathrm{~L} \mathrm{~min}^{-1}$ & $15.0 \mathrm{~L} \mathrm{~min}^{-1}$ & 18.0 $\mathrm{L} \mathrm{min}^{-1}$ \\
\hline Auxiliary gas flow rate & $1.5 \mathrm{~L} \mathrm{~min}^{-1}$ & $1.5 \mathrm{~L} \mathrm{~min}^{-1}$ & $1.8 \mathrm{~L} \mathrm{~min}^{-1}$ \\
\hline Sheath gas flow & ---------------- & -----------------' & $0.21 \mathrm{~L} \mathrm{~min}^{-1}$ \\
\hline Carrier gas flow rate & --------------- & $120 \mathrm{~mL} \mathrm{~min}^{-1}$ & ---------------- \\
\hline Nebulizer pressure & $180 \mathrm{kPa}$ & ---------------- & ---------------- \\
\hline Nebulizer type & Concentric glass $\mathrm{K}$ & ---------------- & ---------------- \\
\hline Spray chamber & Standard Axial Varian & Standard Axial Varian & ---------------- \\
\hline Replicate read time & $15 \mathrm{~s}$ with 4 replicates & $15 \mathrm{~s}$ with 4 replicates & 20 s with 8 replicates \\
\hline Torch type & $1.8 \mathrm{~mm}$ I.D. alumina injector tube & Quartz for axial view & Quartz \\
\hline $\begin{array}{l}\mathrm{NaBH}_{4} \text { concentration } \\
\mathrm{HCl} \text { concentration }\end{array}$ & ----------------- & $\begin{array}{l}0.3 \%(\mathrm{~m} / \mathrm{v}) \text { in } 0.4 \%, \mathrm{~m} / \mathrm{v}, \mathrm{NaOH} \\
5 \mathrm{~mol} \mathrm{~L}^{-1}\end{array}$ & ---------------- \\
\hline $\begin{array}{l}\text { Analytical lines } \\
\text { isotopes (ICP-MS) }\end{array}$ & $\begin{array}{l}\mathrm{Al}: 396.152 \mathrm{~nm}, \mathrm{Ba}: 455.403 \mathrm{~nm} \text {, } \\
\mathrm{Cd}: 214.439 \mathrm{~nm}, \mathrm{Cr}: 267.716 \mathrm{~nm} \text {, } \\
\mathrm{Cu}: 327.395 \mathrm{~nm} \text {; Fe: } 238.204 \mathrm{~nm} \text {, } \\
\mathrm{Li}: 610.365 \mathrm{~nm}, \mathrm{Mn}: 257.610 \mathrm{~nm} \text {, } \\
\mathrm{Ni}: 231.604 \mathrm{~nm}, \mathrm{Sr}: 421.552 \mathrm{~nm}, \\
\mathrm{~V}: 292.401 \mathrm{~nm}, \mathrm{Zn}: 213.857 \mathrm{~nm}\end{array}$ & $\mathrm{Hg}: 252.652 \mathrm{~nm}$ & $\begin{array}{l}{ }^{75} \mathrm{As},{ }^{121} \mathrm{Sb}, \quad{ }^{206,207,208} \mathrm{~Pb} \\
\text { and }{ }^{78} \mathrm{Se}\end{array}$ \\
\hline $\begin{array}{l}\text { Collisional gas CRI } \\
\text { Internal standard }\end{array}$ & ----------------- & ---------------- & $\begin{array}{l}\mathrm{H}_{2}\left({ }^{78} \mathrm{Se}\right) \\
{ }^{89} \mathrm{Y},{ }^{115} \mathrm{In}\end{array}$ \\
\hline
\end{tabular}

In Article "Chemical quality of bottled mineral waters from markets of Curitiba-PRBrazil", with the number of DOI: http://dx.doi.org/10.1590/1678-4324-2016150111, published in journal Brazilian Archives of Biology and Technology, vol. 59, the 03 page.

That read:

"Reagents and samples: All chemicals were of analytical grade, unless otherwise specified. Highpurity water (18.2 $\mathrm{M} \square \mathrm{cm}$ resistivity) was de-ionized in a Milli-Q system (Bedford, MA, USA). The following Merck reagents (Darmstadt, Germany) were used: $\mathrm{NaBH}_{4}$ to prepare a $0.3 \% \mathrm{~m} / \mathrm{v}$ solution in $\mathrm{NaOH} ; 65 \% \mathrm{v} / \mathrm{v} \mathrm{HNO}_{3}$ suprapur ${ }^{\circledR} ; 37 \% \mathrm{v} / \mathrm{v} \mathrm{HCl}$ from which a $5 \mathrm{~mol} \mathrm{~L}^{-1}$ solution was prepared. Buffer solutions for pH 4.00 and pH 7.00 were supplied by Exxodo (Hortolândia, Brasil). Monoelemental standard solutions containing $1000 \square \mathrm{g} \mathrm{mL}^{-1}$ of $\mathrm{Al}, \mathrm{As}, \mathrm{Hg}, \mathrm{In}, \mathrm{K}^{+}, \mathrm{Mn}, \mathrm{Na}^{+}, \mathrm{Pb}, \mathrm{Se}$, $\mathrm{Sb}, \mathrm{Sr}, \mathrm{V}, \mathrm{Y}, \mathrm{Zn}, \mathrm{Cl}^{-}, \mathrm{NO}_{2}{ }^{-}$and $\mathrm{NH}_{4}{ }^{+}$were obtained from AccuStandard (New Haven, USA); those for $\mathrm{Ba}, \mathrm{Cd}, \mathrm{Cr}, \mathrm{Ca}^{2+}, \mathrm{Cu}, \mathrm{Fe}, \mathrm{Li}, \mathrm{Mg}^{2+}$ and $\mathrm{Ni}$ from UltraScientific (North Kingstown, USA), while solutions of $\mathrm{F}^{-}, \mathrm{NO}_{3}{ }^{-}$and $\mathrm{SO}_{4}{ }^{2-}$ were supplied by FlukaAnalitical (St. Louis, USA). A conductivity standard of $84 \mu \mathrm{S} \mathrm{cm}^{-1}$ was obtained from Mettler Toledo. Quality control Certified Reference Materials comprising acidified aqueous solutions containing $100 \mu \mathrm{g} \mathrm{mL}{ }^{-1} \mathrm{As}, \mathrm{Sb}, \mathrm{Ca}, \mathrm{Cd}, \mathrm{Cr}, \mathrm{Cu}$, $\mathrm{Fe}, \mathrm{Li}, \mathrm{Mg}, \mathrm{Mn}, \mathrm{Ni}, \mathrm{Pb}, \mathrm{Se}, \mathrm{Sr}, \mathrm{V}$ and $\mathrm{Zn}$ (QCS-01-5), $100 \mu \mathrm{gL}^{-1}$ of Al, Ba, K and Na (QCS-02$\mathrm{R} 1-5)$ and $20 \mu \mathrm{g} \mathrm{mL}^{-1}$ of $\mathrm{Hg}$ (TCLP-02-1) were obtained from AccuStandard. These served asquality control standards."

Read:

"Reagents and samples: All chemicals were of analytical grade, unless otherwise specified. Highpurity water (18.2 M $\Omega \mathrm{cm}$ resistivity) was de-ionized in a Milli-Q system (Bedford, MA, USA). The following Merck reagents (Darmstadt, Germany) were used: $\mathrm{NaBH}_{4}$ to prepare a $0.3 \% \mathrm{~m} / \mathrm{v}$ solution in $\mathrm{NaOH} ; 65 \% \mathrm{v} / \mathrm{v} \mathrm{HNO}_{3}$ suprapur ${ }^{\circledR} ; 37 \% \mathrm{v} / \mathrm{v} \mathrm{HCl}$ from which a $5 \mathrm{~mol} \mathrm{~L}^{-1}$ solution was prepared. Buffer solutions for $\mathrm{pH} 4.00$ and $\mathrm{pH} 7.00$ were supplied by Exodo (Hortolândia, Brasil). Monoelemental standard solutions containing $1000 \mu \mathrm{g} \mathrm{mL} \mathrm{m}^{-1}$ of $\mathrm{Al}, \mathrm{As}, \mathrm{Hg}, \mathrm{In}, \mathrm{K}^{+}, \mathrm{Mn}, \mathrm{Na}^{+}, \mathrm{Pb}, \mathrm{Se}$, $\mathrm{Sb}, \mathrm{Sr}, \mathrm{V}, \mathrm{Y}, \mathrm{Zn}, \mathrm{Cl}^{-}, \mathrm{NO}_{2}{ }^{-}$and $\mathrm{NH}_{4}^{+}$were obtained from AccuStandard (New Haven, USA); those for $\mathrm{Ba}, \mathrm{Cd}, \mathrm{Cr}, \mathrm{Ca}^{2+}, \mathrm{Cu}, \mathrm{Fe}, \mathrm{Li}, \mathrm{Mg}^{2+}$ and $\mathrm{Ni}$ from UltraScientific (North Kingstown, USA), while solutions of $\mathrm{F}^{-}, \mathrm{NO}_{3}{ }^{-}$and $\mathrm{SO}_{4}{ }^{2-}$ were supplied by Fluka Analitical (St. Louis, USA). A conductivity standard of $84 \mu \mathrm{S} \mathrm{cm}^{-1}$ was obtained from Mettler Toledo. Quality control Certified Reference Materials comprising acidified aqueous solutions containing $100 \mu \mathrm{g} \mathrm{mL}{ }^{-1} \mathrm{As}, \mathrm{Sb}, \mathrm{Ca}, \mathrm{Cd}, \mathrm{Cr}, \mathrm{Cu}$, 
Fe, Li, Mg, Mn, Ni, Pb, Se, Sr, V and Zn (QCS-01-5), $100 \mu \mathrm{g} \mathrm{mL}^{-1}$ of Al, Ba, K and Na (QCS-02$\mathrm{R} 1-5)$ and $20 \mu \mathrm{g} \mathrm{mL}^{-1}$ of $\mathrm{Hg}$ (TCLP-02-1) were obtained from AccuStandard. These served as quality control standards."

In Article "Chemical quality of bottled mineral waters from markets of Curitiba-PRBrazil", with the number of DOI: http://dx.doi.org/10.1590/1678-4324-2016150111, published in journal Brazilian Archives of Biology and Technology, vol. 59, the 06 page.

That read:

Table 4. Figures of merit and results for analysis of quality control materials and standards $(n=7)$.

\begin{tabular}{|c|c|c|c|c|c|c|c|}
\hline Analyte & $\begin{array}{l}\text { Linear } \\
\text { correlationcoefficients }\end{array}$ & $\begin{array}{l}\text { Limit of } \\
\text { detection } \\
\left(\mu \mathrm{g} \mathrm{L}^{-1}\right)\end{array}$ & $\begin{array}{l}\text { Limit of } \\
\text { quantification } \\
\left(\mu \mathrm{g} \mathrm{L}^{-1}\right)\end{array}$ & $\begin{array}{l}\text { expected } \\
\text { concentration } \\
\left(\mu \mathrm{g} \mathrm{L}^{-1}\right)\end{array}$ & recovery & & $\begin{array}{l}\text { RSD, } \\
\%\end{array}$ \\
\hline $\mathrm{Al}$ & 0.9998 & 2 & 10 & 10.0 & $\begin{array}{l}10.0 \\
0.2\end{array}$ & & 2.0 \\
\hline As & 0.9997 & 0.1 & 1.0 & 10.0 & $\begin{array}{l}10.3 \\
0.2\end{array}$ & \pm & 1.9 \\
\hline $\mathrm{Ba}$ & 0.9999 & 1 & 5 & 10.0 & $\begin{array}{l}11.0 \\
0.1\end{array}$ & & 0.9 \\
\hline $\mathrm{Ca}^{2+}$ & 0.9999 & 10 & 100 & 100 & $106 \pm 4$ & & 4 \\
\hline $\mathrm{Cd}$ & 0.9999 & 0.2 & 1.0 & 10.0 & $9.6 \pm 0.1$ & & 1.0 \\
\hline $\mathrm{Cu}$ & 0.9996 & 1 & 10 & 10.0 & $\begin{array}{l}10.1 \\
0.2\end{array}$ & \pm 2 & 2.0 \\
\hline $\mathrm{Cr}$ & 0.9999 & 0.2 & 1.0 & 10.0 & $9.8 \pm 0.1$ & & 1.0 \\
\hline $\mathrm{Cl}^{-}$ & 0.9999 & 30 & 100 & 100 & $101 \pm 10$ & & 10 \\
\hline $\mathrm{F}^{-}$ & 0.9993 & 1 & 20 & 10.0 & $9.1 \pm 0.3$ & & 3.3 \\
\hline $\mathrm{Fe}$ & 0.9999 & 2 & 10 & 10.0 & $\begin{array}{l}10.5 \\
0.1\end{array}$ & \pm & 1.0 \\
\hline $\mathrm{Hg}$ & 0.9980 & 0.04 & 0.2 & 1.0 & $\begin{array}{l}0.9 \\
0.03\end{array}$ & \pm & 3.3 \\
\hline $\mathrm{K}^{+}$ & 0.9999 & 10 & 100 & 100 & $102 \pm 3$ & & 3 \\
\hline $\mathrm{Li}$ & 0.9996 & 2 & 10 & 10.0 & $\begin{array}{l}11.2 \\
0.2\end{array}$ & \pm & 1.8 \\
\hline Mn & 0.9999 & 0.2 & 1.0 & 10.0 & $\begin{array}{l}10.2 \\
0.2\end{array}$ & \pm & 1.8 \\
\hline $\mathrm{Mg}^{2+}$ & 0.9999 & 5 & 100 & 100 & $98 \pm 2$ & & 2 \\
\hline $\mathrm{NO}_{3}^{-}$ & 0.9999 & 5 & 100 & 100 & $89 \pm 1$ & & 1 \\
\hline $\mathrm{NO}_{2}^{-}$ & 0.9999 & 1 & 10 & 10.0 & $\begin{array}{l}10.2 \\
0.3\end{array}$ & \pm 2 & 2.9 \\
\hline $\mathrm{NH}_{4}^{+}$ & 0.9999 & 10 & 30 & 30.0 & $\begin{array}{l}33.0 \\
2.1\end{array}$ & \pm & 6.4 \\
\hline $\mathrm{Na}^{+}$ & 0.9999 & 10 & 100 & 100 & $100 \pm 4$ & & 4 \\
\hline $\mathrm{Ni}$ & 0.9999 & 2 & 10 & 10.0 & $9.5 \pm 0.3$ & & 3.2 \\
\hline $\mathrm{Pb}$ & 0.9995 & 0.1 & 1.0 & 10.0 & $\begin{array}{l}10.2 \\
0.2\end{array}$ & \pm 2 & 2.0 \\
\hline $\mathrm{Sb}$ & 0.9996 & 0.2 & 1.0 & 10.0 & $\begin{array}{l}11.1 \\
0.3\end{array}$ & \pm 2 & 2.7 \\
\hline $\mathrm{Sr}$ & 0.9997 & 1 & 5 & 10.0 & $\begin{array}{l}10.0 \\
0.1\end{array}$ & \pm & 1.0 \\
\hline $\mathrm{Se}$ & 0.9987 & 0.1 & 1.0 & 10.0 & $\begin{array}{l}10.1 \\
0.1\end{array}$ & \pm & 1.0 \\
\hline
\end{tabular}




\begin{tabular}{lllllll}
$\mathrm{SO}_{4}{ }^{2-}$ & 0.9999 & 10 & 100 & 100 & $98 \pm 2$ & 2.0 \\
$\mathrm{~V}$ & 0.9999 & 2 & 10 & 10.0 & $9.0 \pm 0.1$ & 1.1 \\
$\mathrm{Zn}$ & 0.9999 & 2 & 10 & 10.0 & $9.6 \pm 0.3$ & 3.1 \\
\hline
\end{tabular}

Read:

Table 4. Figures of merit and results for analysis of quality control materials and standards $(n=7)$.

\begin{tabular}{|c|c|c|c|c|c|c|}
\hline Analyte & $\begin{array}{l}\text { Linear } \\
\text { correlation } \\
\text { coefficients }\end{array}$ & $\begin{array}{l}\text { Limit of } \\
\text { detection } \\
\left(\mu \mathrm{g} \mathrm{L}^{-1}\right)\end{array}$ & $\begin{array}{l}\text { Limit of } \\
\text { quantification } \\
\left(\mu \mathrm{g} \mathrm{L}^{-1}\right)\end{array}$ & $\begin{array}{l}\text { expected } \\
\text { concentration } \\
\left(\mu \mathrm{g} \mathrm{L}^{-1}\right) \\
\end{array}$ & recovery & RSD, $\%$ \\
\hline $\mathrm{Al}$ & 0.9998 & 2 & 10 & 10.0 & $10.0 \pm 0.2$ & 2.0 \\
\hline As & 0.9997 & 0.1 & 1.0 & 10.0 & $10.3 \pm 0.2$ & 1.9 \\
\hline $\mathrm{Ba}$ & 0.9999 & 1 & 5 & 10.0 & $11.0 \pm 0.1$ & 0.9 \\
\hline $\mathrm{Ca}^{2+}$ & 0.9999 & 10 & 100 & 100 & $106 \pm 4$ & 4 \\
\hline $\mathrm{Cd}$ & 0.9999 & 0.2 & 1.0 & 10.0 & $9.6 \pm 0.1$ & 1.0 \\
\hline $\mathrm{Cu}$ & 0.9996 & 1 & 10 & 10.0 & $10.1 \pm 0.2$ & 2.0 \\
\hline $\mathrm{Cr}$ & 0.9999 & 0.2 & 1.0 & 10.0 & $9.8 \pm 0.1$ & 1.0 \\
\hline $\mathrm{Cl}^{-}$ & 0.9999 & 30 & 100 & 100 & $101 \pm 10$ & 10 \\
\hline $\mathrm{F}^{-}$ & 0.9993 & 1 & 20 & 10.0 & $9.1 \pm 0.3$ & 3.3 \\
\hline $\mathrm{Fe}$ & 0.9999 & 2 & 10 & 10.0 & $10.5 \pm 0.1$ & 1.0 \\
\hline $\mathrm{Hg}$ & 0.9980 & 0.04 & 0.2 & 1.0 & $0.9 \pm 0.03$ & 3.3 \\
\hline $\mathrm{K}^{+}$ & 0.9999 & 10 & 100 & 100 & $102 \pm 3$ & 3 \\
\hline $\mathrm{Li}$ & 0.9996 & 2 & 10 & 10.0 & $11.2 \pm 0.2$ & 1.8 \\
\hline $\mathrm{Mn}$ & 0.9999 & 0.2 & 1.0 & 10.0 & $10.2 \pm 0.2$ & 1.8 \\
\hline $\mathrm{Mg}^{2+}$ & 0.9999 & 5 & 100 & 100 & $98 \pm 2$ & 2 \\
\hline $\mathrm{NO}_{3}^{-}$ & 0.9999 & 5 & 100 & 100 & $89 \pm 1$ & 1 \\
\hline $\mathrm{NO}_{2}^{-}$ & 0.9999 & 1 & 10 & 10.0 & $10.2 \pm 0.3$ & 2.9 \\
\hline $\mathrm{NH}_{4}^{+}$ & 0.9999 & 10 & 30 & 30.0 & $33.0 \pm 2.1$ & 6.4 \\
\hline $\mathrm{Na}^{+}$ & 0.9999 & 10 & 100 & 100 & $100 \pm 4$ & 4 \\
\hline $\mathrm{Ni}$ & 0.9999 & 2 & 10 & 10.0 & $9.5 \pm 0.3$ & 3.2 \\
\hline $\mathrm{Pb}$ & 0.9995 & 0.1 & 1.0 & 10.0 & $10.2 \pm 0.2$ & 2.0 \\
\hline $\mathrm{Sb}$ & 0.9996 & 0.2 & 1.0 & 10.0 & $11.1 \pm 0.3$ & 2.7 \\
\hline $\mathrm{Sr}$ & 0.9997 & 1 & 5 & 10.0 & $10.0 \pm 0.1$ & 1.0 \\
\hline $\mathrm{Se}$ & 0.9987 & 0.1 & 1.0 & 10.0 & $10.1 \pm 0.1$ & 1.0 \\
\hline $\mathrm{SO}_{4}{ }^{2-}$ & 0.9999 & 10 & 100 & 100 & $98 \pm 2$ & 2.0 \\
\hline V & 0.9999 & 2 & 10 & 10.0 & $9.0 \pm 0.1$ & 1.1 \\
\hline $\mathrm{Zn}$ & 0.9999 & 2 & 10 & 10.0 & $9.6 \pm 0.3$ & 3.1 \\
\hline
\end{tabular}

In Article "Chemical quality of bottled mineral waters from markets of Curitiba-PRBrazil", with the number of DOI: http://dx.doi.org/10.1590/1678-4324-2016150111, published in journal Brazilian Archives of Biology and Technology, vol. 59, the 06 page.

That read:

"Tables 5 and 6 summarize results obtained characterizing the twenty-seven commercial samples purchased for this study. The presence of $\mathrm{NH}_{4}{ }^{+}$and $\mathrm{NO}_{2}{ }^{-}$are indicative of microbiological contamination. The concentration of $\mathrm{NH}_{4}{ }^{+}$was below the limit of quantification but for $\mathrm{NO}_{2}{ }^{-}$ samples 14, 19 and $21\left(0.01 \mathrm{mg} \mathrm{L}^{-1}\right)$ concentrations nearthemaximum limit setby Brazilian legislation were evident whereas that for sample $16\left(0.04 \mathrm{mg} \mathrm{L}^{-1}\right)$ exceeded the maximum limit set by RDC $\mathrm{N}^{\circ} 274,2005$, i.e., $0.02 \mathrm{mg} / \mathrm{L}$. "

Read:

"Tables 5 and 6 summarize results obtained characterizing the twenty-seven commercial samples purchased for this study. The presence of $\mathrm{NH}_{4}{ }^{+}$and $\mathrm{NO}_{2}{ }^{-}$are indicative of microbiological 
contamination. The concentration of $\mathrm{NH}_{4}^{+}$was below the limit of quantification but for $\mathrm{NO}_{2}{ }^{-}$ samples 14, 19 and $21\left(0.01 \mathrm{mg} \mathrm{L}^{-1}\right)$ concentrations near the maximum limit set by Brazilian legislation were evident whereas that for sample $16\left(0.04 \mathrm{mg} \mathrm{L}^{-1}\right)$ exceeded the maximum limit set by RDC $\mathrm{N}^{\circ} 274,2005$, i.e., $0.02 \mathrm{mg} / \mathrm{L}$. "

In Article "Chemical quality of bottled mineral waters from markets of Curitiba-PRBrazil", with the number of DOI: http://dx.doi.org/10.1590/1678-4324-2016150111, published in journal Brazilian Archives of Biology and Technology, vol. 59, the 06 page.

That read:

"Iron is only detected in two imported samples from Italy: $10 \mu \mathrm{g} \mathrm{L}^{-1}$ (sample 26) and $21 \mu \mathrm{g} \mathrm{L}^{-1}$ (sample 27), but its concentration is notdeclared on the sample labels. Selenium is present in the range 1.2 - $6.4 \mu \mathrm{g} \mathrm{L}^{-1}$ (four samples) and $\mathrm{V}$ in the range $10-150 \mu \mathrm{g} \mathrm{L}^{-1}$ (ten samples). Sample 24, imported from France, and sample 17, from Paraná State, are identified as containing the highest concentrations of Se: $6.4 \pm 0.3 \mu \mathrm{g} \mathrm{L}^{-1}$ and V: $150 \pm 5 \mu \mathrm{g} \mathrm{L}{ }^{-1}$, respectively. According to Brazilian legislation, these samples should also beclassified as mineral waters "seleniada", i.e., that containselenium at minimum $6 \mu \mathrm{g} \mathrm{L}^{-1}$ and maximum of $10 \mu \mathrm{g} \mathrm{L}^{-1}$, and "vanadica", i.e., that contain vanadium at minimum 30 $\mathrm{g} \mathrm{L}^{-1}$ (Portaria DNPM 540, 2014 and $\mathrm{RDC} \mathrm{N}^{\circ}$ 274, 2005). However, no statementon the label can be found. With respect to trace element content and potential contaminants, all samplesshould have more information concerning their concentrations."

Read:

"Iron is only detected in two imported samples from Italy: $10 \mu \mathrm{g} \mathrm{L}^{-1}$ (sample 26) and $21 \mu \mathrm{g} \mathrm{L}^{-1}$ (sample 27), but its concentration is not declared on the sample labels. Selenium is present in the range 1.2 - $6.4 \mu \mathrm{g} \mathrm{L}^{-1}$ (four samples) and $\mathrm{V}$ in the range $10-150 \mu \mathrm{g} \mathrm{L}^{-1}$ (ten samples). Sample 24, imported from France, and sample 17, from Paraná State, are identified as containing the highest concentrations of Se: $6.4 \pm 0.3 \mu \mathrm{g} \mathrm{L}^{-1}$ and V: $150 \pm 5 \mu \mathrm{g} \mathrm{L}{ }^{-1}$, respectively. According to Brazilian legislation, these samples should also be classified as mineral waters "seleniada", i.e., that conta in selenium at minimum $6 \mu \mathrm{g} \mathrm{L}^{-1}$ and maximum of $10 \mu \mathrm{g} \mathrm{L}^{-1}$, and "vanadica", i.e., that contain vanadium at minimum $30 \mu \mathrm{g} \mathrm{L}^{-1}$ (Portaria DNPM 540, 2014 and $\mathrm{RDC} \mathrm{N}^{\circ}$ 274, 2005). However, no statement on the label can be found. With respect to trace element content and potential contaminants, all samples should have more information concerning their concentrations."

In Article "Chemical quality of bottled mineral waters from markets of Curitiba-PRBrazil", with the number of DOI: http://dx.doi.org/10.1590/1678-4324-2016150111, published in journal Brazilian Archives of Biology and Technology, vol. 59, the 07 page.

That read:

"Although the physico-chemical parameter $\mathrm{pH}$ showed values different from those declared on the labels, as summarized in Table 3, these differences were not significant and in these cases the producers indicate that the values correspond to those characterizing the source of the water. These differences are acceptable since chemical transformations may occur over time that could slightly affect the $\mathrm{pH}$.The $\mathrm{pH}$ range varies from mildly acidic $(5.53 \pm 0.01$, sample 23$)$ toslightlyalkaline (8. $89 \pm 0.10$, sample 24). Alkalinitydueto the presence of $\mathrm{CO}_{3}{ }^{2-}$ was detected in four sampleswherein thereported pHwas8.49 \pm 0.01 (sample 14), $8.79 \pm 0.03$ (sample 17), $8.44 \pm 0.05$ (sample 19) and $8.89 \pm 0.01$ (sample 24). Figure 1shows thecorrelation betweenconductivity and total dissolved solids (TDS)parameterswhich indicatesthat the higher thesample conductivity, the greater the amount ofTDS present. These two parameters are strongly correlated, especially with imported samples 24 (France), 25 (Portugal) and 26 (Italy). Conductivity is in close agreement with declared values except for sample 01 for which a value of $3.7 \pm 0.1 \mu \mathrm{S} \mathrm{cm}^{-1}$ was determined whereas $153 \mu \mathrm{S}$ $\mathrm{cm}^{-1}$ declared, and the producer will require notification." 
Read:

"Although the physico-chemical parameter $\mathrm{pH}$ showed values different from those declared on the labels, as summarized in Table 3, these differences were not significant and in these cases the producers indicate that the values correspond to those characterizing the source of the water. These differences are acceptable since chemical transformations may occur over time that could slightly affect the $\mathrm{pH}$. The $\mathrm{pH}$ range varies from mildly acidic $(5.53 \pm 0.01$, sample 23$)$ to slightly alkaline $\left(8.89 \pm 0.10\right.$, sample 24). Alkalinity due to the presence of $\mathrm{CO}_{3}{ }^{2-}$ was detected in four samples wherein the reported $\mathrm{pH}$ was $8.49 \pm 0.01$ (sample 14), $8.79 \pm 0.03$ (sample 17), $8.44 \pm 0.05$ (sample 19) and $8.89 \pm 0.01$ (sample 24). Figure 1 shows the correlation between conductivity and total dissolved solids (TDS) parameters which indicates that the higher the sample conductivity, the greater the amount of TDS present. These two parameters are strongly correlated, especially with imported samples 24 (France), 25 (Portugal) and 26 (Italy). Conductivity is in close agreement with declared values except for sample 01 for which a value of $3.7 \pm 0.1 \mu \mathrm{S} \mathrm{cm}^{-1}$ was determined whereas $153 \mu \mathrm{S} \mathrm{cm}^{-1}$ declared, and the producer will require notification."

In Article "Chemical quality of bottled mineral waters from markets of Curitiba-PRBrazil", with the number of DOI: http://dx.doi.org/10.1590/1678-4324-2016150111, published in journal Brazilian Archives of Biology and Technology, vol. 59, the 01 page.

That read:

"Likewise,thehardnesspresent in the samplecan be correlatedmainlyto the presenceof $\mathrm{Ca}$ and $\mathrm{Mg}$. Samples24-26 are again highlighted for their significant values present. The main constituent elements reportedon the sample labels include: $\mathrm{HCO}_{3}^{-}, \mathrm{F}^{-}, \mathrm{Cl}^{-}, \mathrm{NO}_{3}{ }^{-}, \mathrm{SO}_{4}{ }^{2-}, \mathrm{Na}^{+}, \mathrm{K}^{+}, \mathrm{Mg}^{2+}, \mathrm{Ca}^{2+}$, $\mathrm{Ba}, \mathrm{Li}$ and $\mathrm{Sr}$. Principal component analysis (PCA) for the concentrations of these analytes is presented in Figure 2, where PC1 is the first principal component, PC2 is the second and PC3 is the third (Dos Santos et al., 2008, Dos Santos et. al., 2012 and Miller, J. N. and Miller, J. C, 2000). PC1 accounts for $47 \%$ of the variance of the data and discriminates samples through the influence of parameters related to $\mathrm{HCO}_{3}^{-}, \mathrm{F}^{-}, \mathrm{Cl}^{-}, \mathrm{Ca}^{2+}$, and $\mathrm{Li}$. $\mathrm{PC} 2$ accounts for $17 \%$ of the variance of the data and discriminates samples on the basis of $\mathrm{SO}_{4}{ }^{2-}$, while $\mathrm{PC} 3$ accounts for $12 \%$ of the variance of the data and is mainly correlated with the presence of $\mathrm{Ba}$ and $\mathrm{Sr}$. Together, $76 \%$ of the variability of the original data is thus accounted for. As evident from Figure 2, the samples are clustered in a main group but five are located in differentregions of thegraph. Samples 23 to 26 are imported: 23 and 24 from France, 25 from Portugal and 26 from Italy. Only sample 22 is from Minas Gerais State, Brazil. Is evident that these samples havedifferentphysicochemicalcompositions, being characterized by relatively high concentrations of salts, manly $\mathrm{HCO}_{3}{ }^{-}$and $\mathrm{Sr}$. Legislation does not specify a value for $\mathrm{Sr}$, and the $\mathrm{HCO}_{3}{ }^{-}$ion is an essential component of mineral waters (Decreto-Lei $7841,1945)$. These fivesamplesare also rich $\mathrm{inF}^{-}$, providing a classification as "fluoridated mineral water", as defined by Brazilian legislation (Portaria DNPM 540, 2014). The concentration of Li is high in samples 22, 24, 25 and 26, also a characteristic of mineral water in accordance with Brazilian legislation (Portaria DNPM 540, 2014). The concentration of $\mathrm{Ba}$ in sample 22 is the highest: $386 \pm 5 \mu \mathrm{g} \mathrm{L}^{-1}$, but below the maximum specified by Brazilian legislation, i.e., $700 \mu \mathrm{g} \mathrm{L}^{-1}$ (RDC N $\left.{ }^{\circ} 274,2005\right)$. The main cluster comprises the majority of the samples that are bottled in the State of Paraná, with the exception of sample 11 from São Paulo State and sample 27 from Italy. This cluster is characteristic of the presence of $\mathrm{NO}_{3}^{-}$. Nitrate may have either a mineral or microbiological origin. Its determinable concentration ranges from $0.10 \mathrm{mg} \mathrm{L}^{-1}-63.05 \mathrm{mg} \mathrm{L}^{-1}$ while samples 01,15 and 25 are below the LOQ. Only sample $10\left(63.05 \mathrm{mg} \mathrm{L}^{-1}\right)$ is above the maximum specified by Brazilian legislation, i.e., $50 \mathrm{mg} / \mathrm{L}\left(\mathrm{RDC} \mathrm{N}^{\circ} 274,2005\right)$, but the label states a value of $3.47 \mathrm{mg} \mathrm{L}^{-1}$ (Table 3). The elevated concentration may be indicative of microbiological contamination which may be harmful tohuman health (Astel et al., 2014). Samples 01,10 and 21 are classified as "fluoridated mineral water", according to their labels; however, in this study, $\mathrm{F}^{-}$wasnot detectedabove $0.02 \mathrm{mg} \mathrm{L}^{-1}$,theminimum, according to Brazilian legislation 
(Portaria DNPM 540, 2014), needed forwaterto beclassified as such. Since the declared valuesare close to the minimum, analytesorptionby the packagingmaterials may have occurred. It is evident that samples 3 and 4 have the same mineral composition. In reality, these samples are from the same region (Apucarana city, State of Paraná), but on the market they have a different identification and no indication that they are from the same producer. In general, it is clear that information declared on the label is different from that arising from analysis of the samples in this work, but it must also be recognized that as the samples are rich in salts, several factors may lead to changes in the composition, however small, including decomposition of $\mathrm{HCO}_{3}{ }^{-}$, sorption of analytes onto the walls of the container material, the time on the market shelf, and proper care during transport and the ambient storage temperature. To make a more qualified analysis of the national samples, a scatter plot based on only national Brazilian samples is presented in Figure 3. Here the PCs account for $73 \%$ of the variability of the original data. As in Figure 2, variability in the compositions of samples are evident wherein the difference of mineral content of sample 22 in relation to others is evident. The sample 10 possibly is contaminated and the samples 15 and 17 show $\mathrm{F}^{-}$content and $\mathrm{Na}^{+}$higher concentrations than others.Clearly, the PCA statistical tool can be very useful for identification

andcomparison ofcompositionsof bottled mineral waters on the market."

Read:

"Likewise, the hardenss present in the sample can be correlated mainly to the presence of $\mathrm{Ca}$ and Mg. Samples 24-26 are again highlighted for their significant values present. The main constituent elements reported on the sample labels include: $\mathrm{HCO}_{3}^{-}, \mathrm{F}^{-}, \mathrm{Cl}^{-}, \mathrm{NO}_{3}^{-}, \mathrm{SO}_{4}^{2-}, \mathrm{Na}^{+}, \mathrm{K}^{+}, \mathrm{Mg}^{2+}, \mathrm{Ca}^{2+}$, $\mathrm{Ba}, \mathrm{Li}$ and Sr. Principal component analysis (PCA) for the concentrations of these analytes is presented in Figure 2, where PC1 is the first principal component, PC2 is the second and PC3 is the third (Dos Santos et al., 2008, Dos Santos et. al., 2012 and Miller, J. N. and Miller, J. C, 2000). PC1 accounts for $47 \%$ of the variance of the data and discriminates samples through the influence of parameters related to $\mathrm{HCO}_{3}^{-}, \mathrm{F}^{-}, \mathrm{Cl}^{-}, \mathrm{Ca}^{2+}$, and $\mathrm{Li}$. PC2 accounts for $17 \%$ of the variance of the data and discriminates samples on the basis of $\mathrm{SO}_{4}{ }^{2-}$, while $\mathrm{PC} 3$ accounts for $12 \%$ of the variance of the data and is mainly correlated with the presence of $\mathrm{Ba}$ and $\mathrm{Sr}$. Together, $76 \%$ of the variability of the original data is thus accounted for. As evident from Figure 2, the samples are clustered in a main group but five are located in different regions of the graph. Samples 23 to 26 are imported: 23 and 24 from France, 25 from Portugal and 26 from Italy. Only sample 22 is from Minas Gerais State, Brazil. Is evident that these samples have different physicochemical compositions, being characterized by relatively high concentrations of salts, manly $\mathrm{HCO}_{3}{ }^{-}$and $\mathrm{Sr}$. Legislation does not specify a value for $\mathrm{Sr}$, and the $\mathrm{HCO}_{3}{ }^{-}$ion is an essential component of mineral waters (Decreto-Lei $7841,1945)$. These five samples are also rich in $\mathrm{F}^{-}$, providing a classification as "fluoridated mineral water", as defined by Brazilian legislation (Portaria DNPM 540, 2014). The concentration of $\mathrm{Li}$ is high in samples 22, 24, 25 and 26, also a characteristic of mineral water in accordance with Brazilian legislation (Portaria DNPM 540, 2014). The concentration of $\mathrm{Ba}$ in sample 22 is the highest: $386 \pm 5 \mu \mathrm{g} \mathrm{L}^{-1}$, but below the maximum specified by Brazilian legislation, i.e., $700 \mu \mathrm{g} \mathrm{L}^{-1}$ (RDC $\left.\mathrm{N}^{\circ} 274,2005\right)$. The main cluster comprises the majority of the samples that are bottled in the State of Paraná, with the exception of sample 11 from São Paulo State and sample 27 from Italy. This cluster is characteristic of the presence of $\mathrm{NO}_{3}^{-}$. Nitrate may have either a mineral or microbiological origin. Its determinable concentration ranges from $0.10 \mathrm{mg} \mathrm{L}^{-1}-63.05 \mathrm{mg} \mathrm{L}^{-1}$ while samples 01,15 and 25 are below the LOQ. Only sample $10\left(63.05 \mathrm{mg} \mathrm{L}^{-1}\right)$ is above the maximum specified by Brazilian legislation, i.e., $50 \mathrm{mg} / \mathrm{L}$ (RDC $\left.\mathrm{N}^{\circ} 274,2005\right)$, but the label states a value of $3.47 \mathrm{mg} \mathrm{L}^{-1}$ (Table 3 ). The elevated concentration may be indicative of microbiological contamination which may be harmful to human health (Astel et al., 2014). Samples 01, 10 and 21 are classified as "fluoridated mineral water", according to their labels; however, in this study, F'was not detected above $0.02 \mathrm{mg} \mathrm{L}^{-1}$, the minimum, according to Brazilian legislation (Portaria DNPM $540,2014)$, needed for water to be classified as such. Since the declared values are close to the 
minimum, analyte sorptionby the packaging materials may have occurred. It is evident that samples 3 and 4 have the same mineral composition. In reality, these samples are from the same region (Apucarana city, State of Paraná), but on the market they have a different identification and no indication that they are from the same producer. In general, it is clear that information declared on the label is different from that arising from analysis of the samples in this work, but it must also be recognized that as the samples are rich in salts, several factors may lead to changes in the composition, however small, including decomposition of $\mathrm{HCO}_{3}{ }^{-}$, sorption of analytes onto the walls of the container material, the time on the market shelf, and proper care during transport and the ambient storage temperature. To make a more qualified analysis of the national samples, a scatter plot based on only national Brazilian samples is presented in Figure 3. Here the PCs account for $73 \%$ of the variability of the original data. As in Figure 2, variability in the compositions of samples are evident wherein the difference of mineral content of sample 22 in relation to others is evident. The sample 10 possibly is contaminated and the samples 15 and 17 show $\mathrm{F}^{-}$content and $\mathrm{Na}^{+}$higher concentrations than others. Clearly, the PCA statistical tool can be very useful for identification and comparison of compositionsof bottled mineral waters on the market."

In Article "Chemical quality of bottled mineral waters from markets of Curitiba-PRBrazil", with the number of DOI: http://dx.doi.org/10.1590/1678-4324-2016150111, published in journal Brazilian Archives of Biology and Technology, vol. 59, the 09 page.

That read:

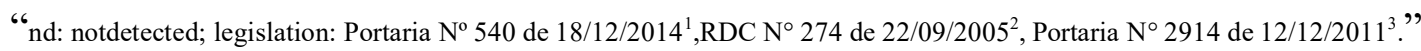

Read:

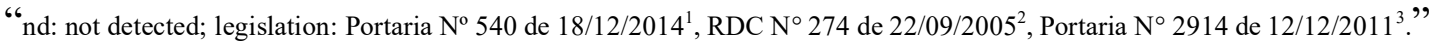

In Article "Chemical quality of bottled mineral waters from markets of Curitiba-PRBrazil", with the number of DOI: http://dx.doi.org/10.1590/1678-4324-2016150111, published in journal Brazilian Archives of Biology and Technology, vol. 59, the 06 page.

That read:

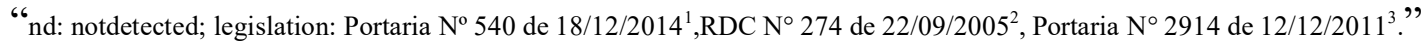

Read:

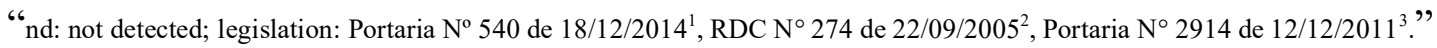

In Article "Chemical quality of bottled mineral waters from markets of Curitiba-PRBrazil", with the number of DOI: http://dx.doi.org/10.1590/1678-4324-2016150111, published in journal Brazilian Archives of Biology and Technology, vol. 59, the 11 page.

That read:

\section{"CONCLUSIONS}

The present study reveals that, in general, the majority of parameters determined in commercial bottled mineral waters from markets in Curitiba-PR-Brazil are below limits specified by Brazilian legislation. Only one sample was detected as having a high concentration of $\mathrm{NO}_{3}^{-}$, indicating microbiological contamination; some results for $\mathrm{NO}_{2}^{-}$may also reflect the same contamination. Improvements in monitoring throughout the process of filling and points of sale of the samples, with the aim of securing the microbiological quality of bottled mineral waterssold in the region under study may be needed. The comparison of labelled composition to analytical results highlights a difference for mostelements, but it should be noted that intrinsic instabilityas well asother factors such assorption of components onto container surfaces as well as the length of time spent on the shelf, care during transport, and the ambient storage temperature may alter the composition; perhaps a "best before date" could eliminate such discrepancies. In such cases, a furtherstudy of thestability andinteractionwith thepackaging should be performed. Although a perfect division of samples from 
PR State is not achieved according to their mineral composition, PCA scores clearly delineate the imported samples from those from other states.

\section{ACKNOWLEDGEMENTS}

The authors are thankfulto Conselho Nacional de Pesquisas e Desenvolvimento Tecnológico (CNPq, Brazil) for thescholarshiptoDasio R. De Oliveira Júnior andto Financiadora de Estudos e Projetos (FINEP, Brazil) for financial support (Rede de Monitoramento Ambiental Rema/Sibratec)."

Read:

\section{"CONCLUSIONS}

The present study reveals that, in general, the majority of parameters determined in commercial bottled mineral waters from markets in Curitiba-PR-Brazil are below limits specified by Brazilian legislation. Only one sample was detected as having a high concentration of $\mathrm{NO}_{3}^{-}$, indicating microbiological contamination; some results for $\mathrm{NO}_{2}^{-}$may also reflect the same contamination. Improvements in monitoring throughout the process of filling and points of sale of the samples, with the aim of securing the microbiological quality of bottled mineral waters sold in the region under study may be needed. The comparison of labelled composition to analytical results highlights a difference for most elements, but it should be noted that intrinsic instability as well as other factors such as sorption of components onto container surfaces as well as the length of time spent on the shelf, care during transport, and the ambient storage temperature may alter the composition; perhaps a "best before date" could eliminate such discrepancies. In such cases, a further study of the stability and interaction with the packaging should be performed. Although a perfect division of samples from PR State is not achieved according to their mineral composition, PCA scores clearly delineate the imported samples from those from other states.

\section{ACKNOWLEDGEMENTS}

The authors are thankful to Conselho Nacional de Pesquisas e Desenvolvimento Tecnológico (CNPq, Brazil) for the scholarship to Dasio R. De Oliveira Júnior and to Financiadora de Estudos e Projetos (FINEP, Brazil) for financial support (Rede de Monitoramento Ambiental Rema/Sibratec)."

In Article "Chemical quality of bottled mineral waters from markets of Curitiba-PRBrazil", with the number of DOI: http://dx.doi.org/10.1590/1678-4324-2016150111, published in journal Brazilian Archives of Biology and Technology, vol. 59, the 11 page.

That read:

"Portaria No 540 de 18/12/2014: establishesminimumlimits ofnoteworthyelementsfor the classification ofmineral waters - DNPM, Brazil, 2014.

Portaria $N^{\circ} 2914$ de 12/12/2011: Sets forth the proceduresofcontroland surveillance ofwater qualityfor human consumption andits potability standards, Ministry of Health,Brazil, 2011.

RDC N ${ }^{\circ} 274$ de 22/09/2005:approves the Thechnical regulations for water bottled and ices - ANVISA, Brazil, 2005."

Read:

"Portaria $N^{\circ} 540$ de 18/12/2014: establishes minimum limits of noteworthy elements for the classification ofmineral waters - DNPM, Brazil, 2014.

Portaria $N^{\circ} 2914$ de 12/12/2011: Sets forth the procedures of control and surveillance of water quality for human consumption and its potability standards, Ministry of Health,Brazil, 2011. 
RDC N 274 de 22/09/2005:approves the The chnical regulations for water bottled and ices - ANVISA, Brazil, 2005."

In Article "Chemical quality of bottled mineral waters from markets of Curitiba-PRBrazil", with the number of DOI: http://dx.doi.org/10.1590/1678-4324-2016150111, published in journal Brazilian Archives of Biology and Technology, vol. 59, the 11 page.

That read:

"Silva Pereira, M. S.; Dos Reis, B. F. (2012). Spectrophotometric aluminium determination in high salts concentration solution used in hemodyalisisemploingpreconcentration in flow injection. Quim. Nova, 25 (6), 931-934.”

Read:

"Silva Pereira, M. S.; Dos Reis, B. F. (2012). Spectrophotometric aluminium determination in high salts concentration solution used in hemodyalis is employing preconcentration in flow injection. Quim. Nova, 25 (6), 931-934." 